\title{
Aberrant naive CD4+ T Cell differentiation in systemic juvenile idiopathic arthritis is committed to B cell help
}

Julia Kuehn ${ }^{1}$, Susanne Schleifenbaum ${ }^{1}$, Antje Hellige ${ }^{1}$, Carolin Park ${ }^{1}$, Claas Hinze ${ }^{1}$, Helmut Wittkowski ${ }^{1}$, Dirk Holzinger ${ }^{2}$, Dirk Foell ${ }^{1}$ and Christoph Kessel $^{1}$

${ }^{1}$ Pediatric Rheumatology \& Immunology, University Children's Hospital, Muenster, Germany

${ }^{2}$ Department of Pediatric Hematology-Oncology University of Duisburg-Essen, Essen, Germany

Corresponding author: Dr. Christoph Kessel, Department of Pediatric Rheumatology and Immunology, University Children's Hospital Muenster, Domagkstr. 3, 48149 Muenster, Germany; Email: christoph.kessel@uni-muenster.de; Phone: +49-251-83-58176; Fax: +49$251-83-58174$

Author contributions: JK, SS, CP and CK acquired laboratory data; $\mathrm{AH}, \mathrm{CH}, \mathrm{HW}, \mathrm{DH}$ and DF collected and analyzed clinical data; JK, DF and CK designed the study; Data analysis \& interpretation: all authors; JK and CK wrote the manuscript; Manuscript draft \& revision: all authors

COI statement: $\mathrm{CH}$ has received honoraria (lecture fees) from Novartis; HW has received honoraria (lecture fees) from Novartis and Takeda, and travel support from Octapharma and CSL-Behring; DH received speaker fees from Novartis; DF received speaker fees/honoraria from Chugai-Roche, Novartis and SOBI as well as research support from Novartis, Pfizer and SOBI. CK has received consulting fees from Novartis and Swedish Orphan Biovitrum (SOBI) $(<\$ 10,000$ each) and receives research support from Novartis $(>\$ 10,000)$. No other disclosures relevant to this article were reported.

NOTE: This preprint reports new research that has not been certified by peer review and should not be used to guide clinical practice. 
medRxiv preprint doi: https://doi.org/10.1101/2022.02.01.22270100; this version posted February 2, 2022. The copyright holder for this preprint

(which was not certified by peer review) is the author/funder, who has granted medRxiv a license to display the preprint in perpetuity.

All rights reserved. No reuse allowed without permission.

Sources of support: This study was supported by the German Research Foundation (DFG) grant \#FO354/14-1.

Running head: SJIA naïve T cell differentiation is committed to B cell help

Word count: 4028

References: 62

Tables: 1

Manuscript color figures: $5 / 5$

Supplemental figures: 7 
medRxiv preprint doi: https://doi.org/10.1101/2022.02.01.22270100; this version posted February 2, 2022. The copyright holder for this preprint (which was not certified by peer review) is the author/funder, who has granted medRxiv a license to display the preprint in perpetuity.

All rights reserved. No reuse allowed without permission.

Objective: Systemic juvenile idiopathic arthritis (sJIA) features characteristics of autoinflammation and autoimmunity, culminating in chronic arthritis. Previous work indicated decreased IFN $\gamma$-expression by $\mathrm{T}$ helper (Th) cells in sJIA. Here, we hypothesized this to result from aberrant or incomplete Th cell polarization.

Methods: Cells or sera were obtained from healthy controls $(\mathrm{HC}, \mathrm{n}=26)$ and sJIA patients $(\mathrm{n}=61)$. Isolated naïve Th cells were cultured under Th1, Th17, and $\mathrm{T}$ follicular or $\mathrm{T}$ peripheral helper (Tf/ph) polarizing conditions and were partly co-cultured with allogenic memory B cells. Surface marker, transcription factor, and/or cytokine expression in peripheral or polarized Th cells or sera as well as B cellular plasma blast generation were studied by flow cytometry, multiplexed bead array assays, ELISA and retrospective RNA profiling analyses.

Results: SJIA naive Th cell differentiation towards Th1 resulted in low IFN $\gamma$ and Eomesodermin expression. Instead, developing sJIA Th1 cells revealed elevated IL-21 release that negatively correlated with cellular IFN $\gamma$ and Eomesodermin expression. Both In vitro and ex vivo, IL-21 together with PD-1, ICOS and CXCR5 expression indicated naïve sJIA Th cell differentiation to rather polarize towards a Tf/ph phenotype. Retrospective analysis of whole blood RNA sequencing data demonstrated sJIA-specific overexpression of Bcl-6 as respective master transcription factor. Compared to controls, in vitro generated sJIA Tf/ph cells promoted enhanced B cellular plasma-blast generation.

Conclusion: In sJIA pathogenesis skewing of sJIA naïve Th cell differentiation towards a Tf/ph phenotype may represent an echo of autoimmunity, which could shed light on the mechanisms driving the progression towards chronic destructive arthritis. 
medRxiv preprint doi: https://doi.org/10.1101/2022.02.01.22270100; this version posted February 2, 2022. The copyright holder for this preprint (which was not certified by peer review) is the author/funder, who has granted medRxiv a license to display the preprint in perpetuity.

All rights reserved. No reuse allowed without permission.

\section{Introduction}

Systemic juvenile idiopathic arthritis (sJIA), or Still's disease, is a unique childhood arthritis entity in that it features characteristics of both autoinflammation and autoimmunity(1). Recent studies indicated that sJIA shows a unique genetic architecture, which manifests in a clinical phenotype distinct from other forms of juvenile arthritis(2). Pathogenetic understanding in sJIA is, however, still limited(3).

At disease onset, the clinical presentation of sJIA is dominated by features prevalent in autoinflammatory fever syndromes. Common symptoms comprise quotidian spiking fever accompanied by an erythematous rash, whereas arthritis may be minimal or even absent. Hepatosplenomegaly, lymphadenopathy, and/or serositis are additional clinical hallmarks that separate sJIA from the other JIA subtypes(4). SJIA can be complicated by macrophage activation syndrome (MAS), a severe hyperinflammatory cytokine storm condition that can result in multi-organ failure with significant mortality(5). If untreated or treatment-refractory, sJIA can progress to chronic destructive arthritis, clinically resembling autoimmunity-driven $\operatorname{arthritis}(5,6)$.

Substantial data underpin the predominance of innate immunity in the early systemic phase of sJIA(3). Therapeutic IL-1 blockade significantly improves disease outcomes(7) and seems particularly effective when initiated as first-line therapy during the systemic disease phase(810). Current data suggest, that children with established polyarthritis are less likely to respond to treatment with recombinant IL-1 receptor antagonist (IL-1Ra; anakinra) $(11,12)$, but may rather benefit from therapeutic IL-6 receptor (IL-6R) blockade (tocilizumab)(13, 14). According to the bi-phasic model of sJIA pathogenesis, innate immunity drives early systemic inflammation but can eventually prime (innately) adaptive immune cells which may then promote chronic destructive arthritis $(3,6)$; immediate biologic treatment in the early systemic phase has been proposed as "a window of opportunity" to abrogate arthritis evolution(6).

A genetic association of sJIA with the major histocompatibility complex (MHC) class II 
medRxiv preprint doi: https://doi.org/10.1101/2022.02.01.22270100; this version posted February 2, 2022. The copyright holder for this preprint (which was not certified by peer review) is the author/funder, who has granted medRxiv a license to display the preprint in perpetuity.

All rights reserved. No reuse allowed without permission.

specific allele $H L A-D R B 1 * 11(15)$, Th17 cell reprogramming(16) as well as alterations in adaptive immune cell signatures(17) or cells rather bridging innate and adaptive immunity $(\gamma \delta$ T cells, NK cells $)(17,18)$ may indeed suggest an autoimmune component to sJIA $(6,19)$. A growing body of evidence points to a special, supposably dichotomous role for the T cellular cytokine IFN $\gamma$ and IFN $\gamma$-signaling in the sJIA-specific continuum of inflammation. Murine models suggested IFN $\gamma$ as a key driver of the anemia in MAS(20) and IFN $\gamma$-inhibition reverted clinical and laboratory MAS features $(21,22)$. Similarly, patient data demonstrated that IFN $\gamma$-neutralization or inhibition of downstream signaling can control MAS(23-26).

Although a crucial role of IFN $\gamma$ in MAS pathophysiology is indisputable, its role in active sJIA without MAS is less clear. Analyzing cytokine levels in active sJIA without present or future MAS indicated either no(27-29) or only partial elevation(30, 31) of IFN $\gamma$ or CXCL9 (as surrogate of IFN $\gamma$ signaling). Monocytes obtained from active sJIA patients rather pointed to a limited in vivo exposure to $\operatorname{IFN} \gamma(32,33)$. Further, a sJIA mouse model requires absence of $\operatorname{IFN} \gamma\left(\operatorname{IFN} \gamma^{-1-}\right)$ to induce disease $(34,35)$. Collectively, these data rather suggested a limited or even opposing role for IFN $\gamma$ in sJIA development(33); it may even protect from sJIA progression as IFN $\gamma$ has been shown to inhibit IL-1 signaling in $\mathrm{PBMCs}(30)$.

We have previously observed decreased IFN $\gamma$ expression in CD4+ T cells of both active and inactive sJIA patients(18). In the present study we hypothesized that due to the likely lack of cognate sJIA-associated $\mathrm{T}$ cell antigens within an in vivo environment of proinflammatory mediators driving $\mathrm{T}$ cell polarization into different directions, CD4+ $\mathrm{T}$ cells in sJIA may suffer from aberrant or incomplete polarization, which may translate into insufficient IFN $\gamma$ expression.

\section{Patients \& Methods}

Study individuals 
medRxiv preprint doi: https://doi.org/10.1101/2022.02.01.22270100; this version posted February 2, 2022. The copyright holder for this preprint (which was not certified by peer review) is the author/funder, who has granted medRxiv a license to display the preprint in perpetuity.

All rights reserved. No reuse allowed without permission.

Blood samples and clinical data for all cell experiments were collected from sJIA patients $(\mathrm{n}=27$, active disease $(A D), n=11$; inactive disease $(\mathrm{ID}), \mathrm{n}=16)$ and pediatric $\operatorname{HCs}(\mathrm{n}=15)$ at the University Hospital in Münster, Germany between March 2016 and November 2021. The study was approved by the local ethics committee (2015-670-f-S) and all parents or care givers singed written informed consent. Systemic JIA patients were diagnosed according to the German consensus criteria(36). Active disease (AD) was defined as the presence of arthritis and/or fever and/or rash, while the absence of arthritis, fever, and rash was classified as inactive disease (ID). Patients diagnosed with macrophage activation syndrome (MAS) met the 2016 classification criteria for MAS complicating $\operatorname{sJIA}(37,38)$. Serum samples were collected from sJIA patients ( $n=34$; active disease $(A D), n=25$; inactive disease (ID), $n=9$ ) and pediatric HCs $(n=10)$ in course of a larger study as recently reported by us(39). Collective demographic and clinical characteristics are summarized in Table $\mathbf{1 .}$

Isolation, (co-)cultures and stimulation of naïve Thelper (Th) cells

Naïve Th cells were isolated from PBMCs and stimulated as described in the supplementary methods section.

Flow cytometry, multiplexed bead array assay and ELISA

Flow cytometry of in vitro differentiated cells or PBMCs and multiplexed bead array assays or ELISA of sera and cell culture supernatants were performed as detailed in the

\section{supplementary methods section.}

\section{Statistical analyses}

Data analyses were performed using GraphPad Prism software (Version 8.0 for Mac OS X, Graphpad Software, La Jolla, CA, USA) and R studio as detailed in the supplemental 
medRxiv preprint doi: https://doi.org/10.1101/2022.02.01.22270100; this version posted February 2, 2022. The copyright holder for this preprint

(which was not certified by peer review) is the author/funder, who has granted medRxiv a license to display the preprint in perpetuity.

All rights reserved. No reuse allowed without permission.

methods section and figure legends. Corrected $P<0.05$ was considered statistically significant. 


\section{Results}

\section{Naive CD4+ T cell differentiation in SJIA to Th1 and IFN $\gamma$ production is impaired and skewed toward low Eomesodermin expression}

Naive CD4+ T cells were isolated from HCs $(n=7)$ and active $(n=5)$ as well as diseaseinactive (n=9) sJIA patients (Table 1). Cells were driven toward either Th1 (Figure 1A, B) or Th17 polarization (Figure S2A, B) by indicated conditions. Subsequent to all $\mathrm{T}$ cell polarizations, cells were super-stimulated using PMA/ionomycin and tested for expression of IFN $\gamma$, IL-17A, T-bet, ROR $\gamma t$ and Eomesodermin by flow cytometry. T cell activation with anti-CD3/CD28 without polarizing cytokines resulted in low IFN $\gamma$, IL-17A and Th1/Th17 transcription factor expression (Figure 1B, C; S2B, C). Yet, IFN $\gamma$ was tightly associated with T-bet expression (Figure 1F). Following Th1 polarization including IL-2 and IL-12 stimulation, IFN $\gamma$ expression by healthy control naïve T cells was markedly increased over cytokine production by sJIA T cells, particularly from patients with inactive disease (Figure 1B, D) and was tightly associated with Eomesodermin rather than T-bet expression (Figure 1G). A similar IFN $\gamma$ expression pattern and IFN $\gamma$-Eomesodermin association was observed when including IL-17A (Figure 1 B, E, H) or IL-18 (Figure 1B, S1) into the Th1 polarizing cytokine cocktail. In contrast to IFN $\gamma$, both IL-17A and ROR $\gamma$ t expression was hardly elevated in all tested Th17 polarizing conditions (Figure S2B, C). Compared to healthy controls and inactive disease patients, cells obtained from patients in course of active sJIA tended to express more IL-17A (Figure S2B, C).

Thus, based on cellular expression, we observed only marginal IFN $\gamma$ and Eomes expression particularly among cells obtained from inactive sJIA patients when driven toward Th1 differentiation. 
medRxiv preprint doi: https://doi.org/10.1101/2022.02.01.22270100; this version posted February 2, 2022. The copyright holder for this preprint (which was not certified by peer review) is the author/funder, who has granted medRxiv a license to display the preprint in perpetuity.

All rights reserved. No reuse allowed without permission.

\section{Developing SJIA Th1 cells reveal elevated IL-21 release in a negative correlation with}

\section{IFN $\gamma$ and Eomesodermin expression}

Apart from analyzing intracellular cytokine and transcription factor expression, we also quantified IFN $\gamma$, IL-17A, IL-21 and IL-22 release if enough cells to prepare respective samples were available (Figure 2A, B, S3A). Except for one active sJIA patient with future MAS, we observed naïve sJIA T cells stimulated only by CD3/CD28-ligation to release less IFN $\gamma$ compared to healthy controls (Figure 2C, left panel; S3B). Conversely, we noted elevated IL-21 production reciprocal to IFN $\gamma$ release (Figure 2C). We further observed, that the phenotype of low IFN $\gamma$ expression by sJIA $\mathrm{T}$ cells was lost with increasing cytokine concentrations in supernatants in course of Th1 differentiation (Figure 2B, D-E: left panels), thus contrasting our flow cytometry data at intracellular production level. However, the increased IL-21 expression by sJIA T cells was consistent over almost all differentiating conditions (Figure 2B, C-E: middle panels; S3C) and remained in reciprocal association with IFN $\gamma$ release, albeit below significance level (Figure 2 C-E: right panels). In part consistent with our cellular expression data (Figure S2 B, C) we did not detect elevation in IL-17A or IL-22 release in any of the tested conditions, unless present in the respective stimulation cocktail (Figure S3A, C).

IL-21 is produced by NKT cells as well as several CD4+ T cellular subsets. Importantly, IL21 plays a pivotal role in peripheral $\mathrm{T}$ cell differentiation(40) and can inhibit IFN $\gamma$ production in developing Th1 cells through Eomesodermin repression(41). As our flow cytometry data already indicated a tight correlation of IFN $\gamma$ and Eomesodermin expression in course of Th1 differentiation, we now tested the association of IL-21 release with cellular IFN $\gamma$ and Eomesodermin expression (Figure 2F, G). Among experiments for which both cytokine release and flow cytometry data were available, we observed a marked negative correlation of IL-21 in culture supernatants with both IFN $\gamma$ and Eomesodermin but not T-bet expression 
medRxiv preprint doi: https://doi.org/10.1101/2022.02.01.22270100; this version posted February 2, 2022. The copyright holder for this preprint (which was not certified by peer review) is the author/funder, who has granted medRxiv a license to display the preprint in perpetuity.

All rights reserved. No reuse allowed without permission.

(Figure 2F). Further, we noted that recombinant IL-21 present during Th1 differentiation of HD naïve CD4+ T cells to significantly reduce IFN $\gamma$ expression (Figure S4). In addition, we observed a positive association of IL-21 release with cellular IL-17 but not ROR $\gamma t$ production among designated Th17 polarizing conditions (Figure 2G).

Collectively our data suggest elevated IL-21 expression by sJIA T cells impairs IFN $\gamma$ production in developing Th1 cells via Eomesodermin repression.

\section{Early Th1 differentiation of sJIA naive peripheral CD4+ T cells is shifted toward a}

\section{Tf/ph phenotype}

Among CD4+ $\mathrm{T}$ helper cell subtypes $\mathrm{T}$ follicular helper $(\mathrm{Tfh})$ cells have been reported to produce IL-21 at particularly high levels. Besides high IL-21 release, Tfh cells are hallmarked by cell surface expression of PD-1, ICOS and CXCR5(42), while a peripheral/tissue-resident counterpart arising in context of chronic inflammation (peripheral $\mathrm{T}$ helper (Tph) cells) has been reported to express no or only marginal surface levels of CXCR5(43-45).

Our objective for the next set of experiments was to investigate whether - in the tested conditions - naïve sJIA Th cells might differentiate toward Tf/ph rather than Th1 cells. Therefore, naïve CD4+ T cells from HCs $(n=5)$ and active $(n=3)$ as well as disease-inactive $(\mathrm{n}=4)$ sJIA patients (Table 1) were driven toward either Th1 or Tf/ph polarization by the indicated conditions (Figure 3 A, B). Subsequently, cells were super-stimulated using PMA/ionomycin and were analyzed for expression of IFN $\gamma$, IL-21, PD-1, ICOS and CXCR5 by flow cytometry. Among all tested conditions and albeit cytokine expression levels were generally lower in these experiments compared to previous results (Figure 1), we again observed the pattern of elevated IFN $\gamma$ expression by HCs versus sJIA CD4+ T cells (Figure 3 B, D, Figure S5). In contrast, we noted particularly naïve CD4+ T cells isolated from inactive sJIA patients to overexpress IL-21, PD-1 and ICOS compared to both active disease patients and HCs (Figure 3B, D; Suppl. Figure S5). IFN $\gamma$ and IL-21 expression were markedly 
medRxiv preprint doi: https://doi.org/10.1101/2022.02.01.22270100; this version posted February 2, 2022. The copyright holder for this preprint (which was not certified by peer review) is the author/funder, who has granted medRxiv a license to display the preprint in perpetuity.

All rights reserved. No reuse allowed without permission.

negatively associated among naïve CD4+ T cells stimulated only by CD3/CD28-ligation

(Figure 3B-D). This association was weaker or lost in course of Th1 differentiation but partly restored upon Tf/ph polarization (Figure 3C, D; S5). Further, intracellular IL-21 production was strongly correlated with cell surface expression of PD-1 throughout (Figure 3C, D; S5). Marked association of IL-21 production and ICOS expression on cells was particularly evident in course of both Th1 and Tf/ph differentiation (Figure 3C). In contrast to high PD-1 and ICOS, we observed only marginal CXCR5 expression throughout (Figure 3B, C). Besides surface marker and intracellular cytokine expression we also quantified the release of IL-21 and CXCL13 as hallmark molecules produced by both follicular and peripheral T helper cells(45). We observed elevated release of both IL-21 and CXCL13 particularly among cells derived from inactive sJIA patients' naïve CD4+ T cells (Figure S6).

Paralleling in vitro experiments, we also performed ex vivo analyses of patients' biomaterial. We observed elevated levels of IL-21 as well as IL-6 and IL-23 as key cytokines involved in Tf/ph differentiation in active sJIA patients (Figure 4A). Further, in PBMC samples of patients with sJIA we observed decreased Th cellular IFN $\gamma$ but elevated IL-21 expression, particularly among CD4+PD-1+ and CD4+CXCR5+ cells in inactive sJIA patients' samples, when compared to pediatric controls (Figure 4B). In these samples IL-21 production was best associated with CXCR5 expression (Figure 4C). Importantly, we also analyzed already available whole blood RNA sequencing data (GSE112057(46)) obtained from healthy controls $(n=12)$ and sJIA $(n=26)$ as well as polyarticular $(n=46)$ and oligoarticular JIA patients (n=43) for sJIA-hallmark (IL1B, ILIR1, IL1RN, S100A12), Tph (CX3CR1, CXCR6, CCR2, CCR5, PRDM1), Tfh (FOS, CXCR5, BCLO), naïve (LRRN2, CCR7, NPM1), central memory $(P A S K)$, effector memory (IL7R, KLRB1,TNFSF13B) and activated effector memory (CCLA, GZMH, GZMA) T cell signature gene expression(47, 48). Beyond, we also looked at IFNG as well as TBX21 (T-bet), EOMES, MAF, and SOX4 transcription (Figure 4D). Expression of most analyzed genes, including IFNG, was decreased in all JIA entities when 
medRxiv preprint doi: https://doi.org/10.1101/2022.02.01.22270100; this version posted February 2, 2022. The copyright holder for this preprint (which was not certified by peer review) is the author/funder, who has granted medRxiv a license to display the preprint in perpetuity.

All rights reserved. No reuse allowed without permission.

compared to healthy controls (Figure 4D, F). However, alongside with elevated expression of $I L 1 B, I L 1 R 1, I L 1 R N$ and S100A12 as hallmarks for sJIA (Figure 4D, E), we also observed strongly elevated expression of BCL6 as well as TNFSF13B, and FOS expression elevated by trend (Figure 4D, F).

Collectively, these data imply Th differentiation in sJIA both in vitro and in vivo to skew toward a Tf/ph phenotype.

\section{Tf/ph cells derived from sJIA naïve CD4+ cells are functional and drive B cellular plasma-blast generation}

Tfh cells reside within B cell follicles to provide B cell help to produce high-affinity antibodies, while Tph cells are thought to drive corresponding plasma-blast generation in the periphery, namely within inflamed tissue(45). Therefore, we aimed to test whether naïve sJIA CD4+ $\mathrm{T}$ cells subjected to Th1 or Tf/ph differentiating conditions would indeed result in functional Tf/ph cells with the ability to drive B cellular plasma-blast generation.

We isolated naïve CD4+ T cells from HCs $(n=4)$ and active $(n=2)$ as well as disease-inactive $(n=3)$ sJIA patients (Table 1). Cells were either cultured with anti-CD3/CD28 or driven toward Th1 (anti-CD3/CD28+IL-2+IL-12) or Tf/ph (anti-CD3/CD28+IL-6+IL-12+IL-21) polarization (Figure 5A). Subsequently, cells were co-cultured with freshly isolated healthy donor memory B cells for six further days and eventual plasma-blast generation $\left(\mathrm{CD}^{-1}{ }^{+} \mathrm{IgD}^{-}\right.$ $\mathrm{CD} 27^{+} \mathrm{CD} 38^{+} \mathrm{CD} 138^{-}$) was analyzed by flow cytometry (Figure 5A). Plasma blasts were defined as $\mathrm{CD}^{+} 9^{+} \mathrm{IgD}{ }^{-} \mathrm{CD} 27^{+} \mathrm{CD} 38^{+} \mathrm{CD} 138^{-}$cells(49) (Figure 5B-D). We found that Tf/ph cells generated from naïve sJIA CD4+ B cells using the indicated conditions resulted in a marked increase in the frequency of plasma-blasts compared to cultures with $C D 3 / C D 28$ ligation without polarizing cytokines (Figure 5D, E). This increase was most pronounced with designated $\mathrm{Tf} / \mathrm{ph}$ differentiating conditions and significantly elevated over healthy controls (Figure 5D-G). 
Finally, we also questioned whether an environment of low IFN $\gamma$ might benefit IL-17A expression from $\gamma \delta \mathrm{T}$ cells, as we previously speculated(18). In these experiments, inflammatory stimulation of $\gamma \delta \mathrm{T}$ cells in co-culture with human monocytes with or without an IFN $\gamma$-neutralizing antibody (Figure S7A) partly depleted IFN $\gamma($ Figure S7B) but significantly enhanced the $\gamma \delta$ T cellular IL-17A release (Figure S7C).

Collectively our data suggest that the differentiation of naïve CD4+ T cells in sJIA is committed to differentiation toward functional $\mathrm{Tf} / \mathrm{ph}$ cells and that an IFN $\gamma$-depleted environment may benefit $\gamma \delta \mathrm{T}$ cellular IL-17A release as an independent pathophysiological sJIA feature. 
medRxiv preprint doi: https://doi.org/10.1101/2022.02.01.22270100; this version posted February 2, 2022. The copyright holder for this preprint (which was not certified by peer review) is the author/funder, who has granted medRxiv a license to display the preprint in perpetuity.

All rights reserved. No reuse allowed without permission.

\section{Discussion}

The contribution of adaptive immunity to sJIA pathogenesis is still unclear. Although the disease is classified among polygenic autoinflammatory syndromes, observations such as an association with the MHCII haplotype $H L A-D R B 1 * 11(15)$ and Treg polarization towards Th17 in chronic sJIA(16) complicate a clear-cut classification. In this context we previously reported $\gamma \delta \mathrm{T}$ cells in sJIA to operate as main source for IL-17A, while we found peripheral Th cells to express comparably little IL-17A and IFN $\gamma$, in particular(18). These observations echoed data from a murine sJIA model, which reported elevated $\gamma \delta$ T cellular IL-17 expression particularly on IFN $\gamma$-/- background(34) as well as reports suggesting limited in vivo cell exposure to circulating $\operatorname{IFN} \gamma(33)$.

In the present study, we report that in sJIA, the differentiation of naïve peripheral Th cells towards a Th1 and IFN $\gamma$ production is impaired and instead skewed towards a Tf/ph phenotype. This we observed particularly among cells obtained from inactive patients while in vitro differentiated cells were hallmarked by elevated IL-21 and CXCL13 production and cell-surface expression of PD-1 and ICOS. Ex vivo analyses mirrored in vitro data in that we found elevated IL-21 expression both at cellular as well as serum level and identified BCL6 as a master transcription factor for $\mathrm{Tf} / \mathrm{ph}$ differentiation(50-52) as highly overexpressed in retrospective analyses of sJIA whole blood RNA sequencing data(46). Finally, in vitro generated sJIA Tf/ph cells proofed functional as they could drive plasma blast generation from allogenic memory B cells.

In line with the window-of-opportunity model of sJIA pathogenesis and our as well as others' previous data, the central aim of our study was to investigate the power of the sJIA cytokine environment on influencing Th cell differentiation. Surprisingly, we observed Th cell differentiation in sJIA to be altered already at naïve T cell level. Even when removed from the 
medRxiv preprint doi: https://doi.org/10.1101/2022.02.01.22270100; this version posted February 2, 2022. The copyright holder for this preprint (which was not certified by peer review) is the author/funder, who has granted medRxiv a license to display the preprint in perpetuity.

All rights reserved. No reuse allowed without permission.

individual sJIA patient environment and exposed to controlled in vitro stimulating conditions, naïve sJIA $\mathrm{T}$ cells appeared wired for $\mathrm{Tf} / \mathrm{ph}$ differentiation. Both in in vitro polarization experiments, as well as in ex vivo analyses this was most consistently hallmarked by overexpression of IL-21. Besides Th17 cells, Tf/ph cells are the most prominent producers of IL-21(40). Yet, in our experiments, Th1 differentiating conditions applied on sJIA naïve T cells resulted in massive IL-21 release, while Th17 polarizing stimuli also promoted IL-21 production in positive correlation with IL-17A; yet, this was far less than seen with sJIA T cells driven towards Th1.

Besides high expression of IL-21 and the B cell chemoattractant CXCL13(53), Tfh cells are hallmarked by PD-1, ICOS and CXCR5 expression. However, in developing sJIA Th cells cultured under Th1 or Tf/ph polarizing conditions in vitro, we only detected marginal CXCR5 expression. The observed PD-1+ICOS+CXCR5- phenotype is rather characteristic for Tph cells, a subset of Th cells that has recently been described to activate memory B cells within inflamed tissues and contribute to the formation of tertiary lymphoid organs (TLO) in different autoimmune conditions(43-45).

Ex vivo, we found both CD4+PD-1+CXCR5+ and CD4+PD-1+CXCR5- cells to reveal increased cellular IL-21 production, which particularly correlated with CXCR5 expression. In addition, retrospective analyses of whole blood RNA sequencing data (GSE112057(46)) demonstrated an sJIA-specific overexpression of the Tfh master transcription factor Bcl-6(5052). Importantly, whole transcriptome transcription factor motif enrichment analyses previously reported Bcl-6 to be amongst the most prominent binding motifs in sJIA immune cells(54). In contrast, we found no relevant elevation of transcription factor expression such as of Sox-4 (SOX4) or Blimp-1 (PRDM1)(43-45) or of other genes (CX3CR1, CXCR6, CCR2, CCR5)(47) reported to rather associate with Tph differentiation. 
medRxiv preprint doi: https://doi.org/10.1101/2022.02.01.22270100; this version posted February 2, 2022. The copyright holder for this preprint (which was not certified by peer review) is the author/funder, who has granted medRxiv a license to display the preprint in perpetuity.

All rights reserved. No reuse allowed without permission.

Comparing our in vitro and in vivo data, it might appear that in vivo, sJIA Th cells are preferentially skewed toward a Tfh and to a lesser extent towards a Tph cell phenotype as observed in in vitro experiments. However, most likely, Tfh and Tph cells co-evolve from a common naïve Tf/ph precursor cell in secondary lymphoid organs (SLOs) under the influence of stimuli favoring the polarization towards both lineages. The tipping point that eventually defines a Tfh or Tph fate is yet unknown(45). Further, Tph cell detection in the circulation may be challenging, as particularly in inflammatory conditions Tph cells mature and reside in inflamed tissue. In addition, immature circulating Tph (cTph) cells presumably express CXCR5 at low levels, which makes them hardly distinguishable from circulating $\mathrm{Tfh}$ (cTfh) cells(45). Collectively, this can explain why our in vivo data point towards a Tfh dominance in circulation, while our in vitro experiments mimicking the pro-inflammatory cytokine environment at the site of inflammation may rather give rise to cells of a Tph phenotype. Regardless of these subtle differences, our data suggest that in sJIA naïve Th cell differentiation is wired for a $\mathrm{Tf} / \mathrm{ph}$ precursor phenotype that in dependency on localization and stimuli can mature into either Tfh cells in SLOs or into Tph cells at sites of inflammation.

The precise molecular mechanisms that result in a skewing of naïve sJIA Th cell differentiation toward a Tf/ph phenotype remain yet elusive. Tf/ph polarizing stimuli include activin A, IL-12, IL-23, TGF $\beta$ and IL-6, that via STAT3 and STAT4 signaling promote the expression of IL-21 and IL-21R, which in turn fosters Tfh differentiation in an autocrine manner( 55,56$)$. We and others observed elevated serum levels of IL-23 and IL-6 in sJIA that might favor Tf/ph polarization and increased STAT3 and STAT4 signaling as well as elevated IL-23R expression in sJIA patients has been reported elsewhere(54). Hence, Tf/ph polarization in sJIA might be incited by elevated levels of Tf/ph polarizing cytokines. Another crucial factor that favors Tf/ph differentiation over Th1 differentiation is the oppression of Eomesodermin expression(57). Importantly, IL-21 has been described to impair 
medRxiv preprint doi: https://doi.org/10.1101/2022.02.01.22270100; this version posted February 2, 2022. The copyright holder for this preprint (which was not certified by peer review) is the author/funder, who has granted medRxiv a license to display the preprint in perpetuity.

All rights reserved. No reuse allowed without permission.

Eomesodermin expression and thereby limit IFN $\gamma$ production in developing Th1 cells(41). In our study, negative correlation of IL-21 release with cellular IFN $\gamma$ and Eomesodermin expression as well as proof-of-principle data of recombinant IL-21 impairing IFN $\gamma$ production from Th1 polarized HC naïve T cells support this concept. Hence, developing sJIA Tfh/Tph cells might stabilize their phenotype in an autocrine manner via the release of IL-21, that in turn impairs Eomesodermin and IFN $\gamma$ expression.

Of note, in the in vitro differentiation experiments we observed the Tph phenotype in developing Th cells to arise particularly from naïve $\mathrm{T}$ cells isolated from inactive sJIA patients. This was mirrored by ex vivo observations. While in the ex vivo setting this may reflect that cells in active patients preferentially move to inflamed tissue rather than to reside in the periphery, the enhanced wiring toward in vitro Tph differentiation of naïve $\mathrm{T}$ cells obtained from inactive versus active sJJA patients is puzzling. Interestingly, we observed that the addition of IL-18 as a cytokine highly overexpressed in active sJIA(58) as well as IL-17A partly restored the expression of IFN $\gamma$ and Eomes in developing active but not inactive sJIA patients' Th cells. Hence, we speculate that naïve Th cells isolated from active patients originate from an environment of high IL-18 as well as other pro-inflammatory cytokines, and consequently might be less prone to impaired Th1 cell differentiation. Yet, further studies are required to define whether these data indicate a rescued Th1 phenotype or the polarization toward a subset of IFN $\gamma$-expressing Tph/Tfh cells, as reported in context of rheumatoid arthritis(59). Nonetheless, regardless of disease activity status we observed elevated IL-21 release and a decreased IFN $\gamma$ and Eomesodermin expression in developing Th cells even if cells underwent no stimulation other than by CD3/CD28-ligation. In summary, this indicates a preferential differentiation toward a Tf/ph over a Th1 phenotype as a general pattern in sJIA. Intriguingly, in oligo- and polyarticular JIA naïve $\mathrm{T}$ cell differentiation toward Th1 was reported to rather skew toward an inflammatory effector Th1.17 and Th17 subtype(60). In 
medRxiv preprint doi: https://doi.org/10.1101/2022.02.01.22270100; this version posted February 2, 2022. The copyright holder for this preprint (which was not certified by peer review) is the author/funder, who has granted medRxiv a license to display the preprint in perpetuity.

All rights reserved. No reuse allowed without permission.

light of our present data, this suggests aberrant Th cell polarization as a general phenomenon in both systemic and non-systemic JIA.

Nonetheless, our observations must be interpreted in the light of three main limitations. 1) Most of our experiments comprise relatively limited patient numbers and we did not have access to cells from other compartments than the periphery. Yet, we used independent patient cohorts for the initial Th1/Th17 differentiation and subsequent Th1/Tfh polarization experiments, which were consistent in main study findings such as elevated IL-21 but decreased IFN $\gamma$ expression. Further, retrospective analyses of whole blood RNA sequencing data revealing sJIA-specific BCL6 overexpression strengthen our data on a different level. 2) We did not harmonize patients for specific disease activity features as well as disease duration and we cannot rule out an underlying confounding effect on our observations. 3) Finally, even though we demonstrate functionality of the Tf/ph cells arising from naïve sJIA $\mathrm{T}$ cells in terms of driving B cellular plasma blast generation, we cannot yet pinpoint their specific contribution to sJIA pathogenesis or progression. Existing data on presence of antinuclear antibodies and rheumatoid factor in arthritic sJIA patients are still limited to small overall patient numbers(61).

Despite these limitations, we believe our observations to contribute to the understanding of sJIA pathogenesis, suggesting a role of adaptive immune cells, namely $\mathrm{Tf} / \mathrm{ph}$ cells in disease, in line with the bi-phasic model of disease progression $(3,6)$. Intriguingly, as an important cytokine in Tf/ph polarization, IL-6 targeting therapies, which are considered second-line therapeutic options in refractory arthritic disease, might interfere with respective Th cell differentiation. Longitudinal data collection could define the impact of cytokine blocking therapies on the $\mathrm{Tf} / \mathrm{ph}$ compartment in sJIA. Of note, treatments specifically blocking $\mathrm{Tf} / \mathrm{ph}$ polarization by interrupting IL-21 signaling have proved safe and effective in first clinical trials in rheumatoid arthritis(62). 
medRxiv preprint doi: https://doi.org/10.1101/2022.02.01.22270100; this version posted February 2, 2022. The copyright holder for this preprint (which was not certified by peer review) is the author/funder, who has granted medRxiv a license to display the preprint in perpetuity.

All rights reserved. No reuse allowed without permission. 
medRxiv preprint doi: https://doi.org/10.1101/2022.02.01.22270100; this version posted February 2, 2022. The copyright holder for this preprint (which was not certified by peer review) is the author/funder, who has granted medRxiv a license to display the preprint in perpetuity.

All rights reserved. No reuse allowed without permission.

\section{References}

1. Petty RE, Southwood TR, Manners P, Baum J, Glass DN, Goldenberg J, et al. International League of Associations for Rheumatology classification of juvenile idiopathic arthritis: second revision, Edmonton, 2001. J Rheumatol. 2004;31(2):390-2.

2. Ombrello MJ, Arthur VL, Remmers EF, Hinks A, Tachmazidou I, Grom AA, et al. Genetic architecture distinguishes systemic juvenile idiopathic arthritis from other forms of juvenile idiopathic arthritis: clinical and therapeutic implications. Ann Rheum Dis. 2017;76(5):906-13.

3. Kessel C, Hedrich CM, Foell D. Innately Adaptive or Truly Autoimmune: Is There Something Unique About Systemic Juvenile Idiopathic Arthritis? Arthritis Rheumatol. 2020;72(2):210-9.

4. Pardeo M, Bracaglia C, De Benedetti F. Systemic juvenile idiopathic arthritis: New insights into pathogenesis and cytokine directed therapies. Best practice \& research Clinical rheumatology. 2017;31(4):505-16.

5. Erkens R, Esteban Y, Towe C, Schulert G, Vastert S. Pathogenesis and Treatment of Refractory Disease Courses in Systemic Juvenile Idiopathic Arthritis: Refractory Arthritis, Recurrent Macrophage Activation Syndrome and Chronic Lung Disease. Rheum Dis Clin North Am. 2021;47(4):585-606.

6. Nigrovic PA. Review: is there a window of opportunity for treatment of systemic juvenile idiopathic arthritis? Arthritis Rheumatol. 2014;66(6):1405-13.

7. Pascual V, Allantaz F, Arce E, Punaro M, Banchereau J. Role of interleukin-1 (IL-1) in the pathogenesis of systemic onset juvenile idiopathic arthritis and clinical response to IL-1 blockade. J Exp Med. 2005;201(9):1479-86.

8. Nigrovic PA, Mannion M, Prince FHM, Zeft A, Rabinovich CE, van Rossum MAJ, et al. Anakinra as First-Line Disease-Modifying Therapy in Systemic Juvenile Idiopathic 
medRxiv preprint doi: https://doi.org/10.1101/2022.02.01.22270100; this version posted February 2, 2022. The copyright holder for this preprint (which was not certified by peer review) is the author/funder, who has granted medRxiv a license to display the preprint in perpetuity.

All rights reserved. No reuse allowed without permission.

Arthritis Report of Forty-Six Patients From an International Multicenter Series. Arthritis Rheum-Us. 2011;63(2):545-55.

9. Vastert SJ, de Jager W, Noordman BJ, Holzinger D, Kuis W, Prakken BJ, et al. Effectiveness of First-Line Treatment With Recombinant Interleukin-1 Receptor Antagonist in Steroid-Naive Patients With New-Onset Systemic Juvenile Idiopathic Arthritis Results of a Prospective Cohort Study. Arthritis \& Rheumatology. 2014;66(4):1034-43.

10. Ter Haar NM, van Dijkhuizen EHP, Swart JF, van Royen-Kerkhof A, El Idrissi A, Leek AP, et al. Treat-to-target using first-line recombinant interleukin-1 receptor antagonist monotherapy in new-onset systemic juvenile idiopathic arthritis: results from a five year follow-up study. Arthritis Rheumatol. 2019.

11. Gattorno M, Piccini A, Lasiglie D, Tassi S, Brisca G, Carta S, et al. The pattern of response to anti-interleukin-1 treatment distinguishes two subsets of patients with systemiconset juvenile idiopathic arthritis. Arthritis Rheum. 2008;58(5):1505-15.

12. Quartier P, Allantaz F, Cimaz R, Pillet P, Messiaen C, Bardin C, et al. A multicentre, randomised, double-blind, placebo-controlled trial with the interleukin-1 receptor antagonist anakinra in patients with systemic-onset juvenile idiopathic arthritis (ANAJIS trial). Ann Rheum Dis. 2011;70(5):747-54.

13. De Benedetti F, Brunner HI, Ruperto N, Kenwright A, Wright S, Calvo I, et al. Randomized trial of tocilizumab in systemic juvenile idiopathic arthritis. The New England journal of medicine. 2012;367(25):2385-95.

14. Ruperto N, Brunner HI, Ramanan AV, Horneff G, Cuttica R, Henrickson M, et al. Subcutaneous dosing regimens of tocilizumab in children with systemic or polyarticular juvenile idiopathic arthritis. Rheumatology (Oxford). 2021;60(10):4568-80.

15. Ombrello MJ, Remmers EF, Tachmazidou I, Grom A, Foell D, Haas JP, et al. HLADRB1*11 and variants of the MHC class II locus are strong risk factors for systemic juvenile idiopathic arthritis. Proc Natl Acad Sci U S A. 2015;112(52):15970-5. 
medRxiv preprint doi: https://doi.org/10.1101/2022.02.01.22270100; this version posted February 2, 2022. The copyright holder for this preprint (which was not certified by peer review) is the author/funder, who has granted medRxiv a license to display the preprint in perpetuity.

All rights reserved. No reuse allowed without permission.

16. Henderson LA, Hoyt KJ, Lee PY, Rao DA, Jonsson AH, Nguyen JP, et al. Th17 reprogramming of T cells in systemic juvenile idiopathic arthritis. JCI Insight. 2020;5(6).

17. Van Nieuwenhove E, Lagou V, Van Eyck L, Dooley J, Bodenhofer U, Roca C, et al. Machine learning identifies an immunological pattern associated with multiple juvenile idiopathic arthritis subtypes. Ann Rheum Dis. 2019;78(5):617-28.

18. Kessel C, Lippitz K, Weinhage T, Hinze C, Wittkowski H, Holzinger D, et al. Proinflammatory cytokine environments can drive IL-17 over-expression by gammadeltaT cells in systemic juvenile idiopathic arthritis. Arthritis Rheumatol. 2017.

19. Nigrovic PA. Autoinflammation and autoimmunity in systemic juvenile idiopathic arthritis. P Natl Acad Sci USA. 2015;112(52):15785-6.

20. Canna SW, Wrobel J, Chu N, Kreiger PA, Paessler M, Behrens EM. Interferongamma mediates anemia but is dispensable for fulminant toll-like receptor 9-induced macrophage activation syndrome and hemophagocytosis in mice. Arthritis Rheum. 2013;65(7):1764-75.

21. Prencipe G, Caiello I, Pascarella A, Grom AA, Bracaglia C, Chatel L, et al. Neutralization of IFN-gamma reverts clinical and laboratory features in a mouse model of macrophage activation syndrome. J Allergy Clin Immunol. 2018;141(4):1439-49.

22. Albeituni S, Verbist KC, Tedrick PE, Tillman H, Picarsic J, Bassett R, et al. Mechanisms of action of ruxolitinib in murine models of hemophagocytic lymphohistiocytosis. Blood. 2019;134(2):147-59.

23. De Benedetti F, Brogan P, Bracaglia C, Pardeo M, Marucci G, Sacco E, et al. Emapalumab (Anti-Interferon-Gamma Monoclonal Antibody) in Patients with Macrophage Activation Syndrome (MAS) Complicating Systemic Juvenile Idiopathic Arthritis (sJIA). Arthritis Rheumatol. 2020;72:14-6. 
medRxiv preprint doi: https://doi.org/10.1101/2022.02.01.22270100; this version posted February 2, 2022. The copyright holder for this preprint (which was not certified by peer review) is the author/funder, who has granted medRxiv a license to display the preprint in perpetuity.

All rights reserved. No reuse allowed without permission.

24. Verweyen E, Holzinger D, Weinhage T, Hinze C, Wittkowski H, Pickkers P, et al. Synergistic Signaling of TLR and IFN alpha/beta Facilitates Escape of IL-18 Expression from Endotoxin Tolerance. Am J Resp Crit Care. 2020;201(5):526-39.

25. Honda M, Moriyama M, Kondo M, Kumakura S, Murakawa Y. Tofacitinib-induced remission in refractory adult-onset Still's disease complicated by macrophage activation syndrome. Scand J Rheumatol. 2020;49(4):336-8.

26. Jorgensen SE, Christiansen M, Host C, Glerup M, Mahler B, Lausten MM, et al. Systemic juvenile idiopathic arthritis and recurrent macrophage activation syndrome due to a CASP1 variant causing inflammasome hyperactivation. Rheumatology (Oxford). 2020;59(10):3099-105.

27. Bracaglia C, de Graaf K, Pires Marafon D, Guilhot F, Ferlin W, Prencipe G, et al. Elevated circulating levels of interferon-gamma and interferon-gamma-induced chemokines characterise patients with macrophage activation syndrome complicating systemic juvenile idiopathic arthritis. Ann Rheum Dis. 2017;76(1):166-72.

28. Weiss ES, Girard-Guyonvarc'h C, Holzinger D, de Jesus AA, Tariq Z, Picarsic J, et al. Interleukin-18 diagnostically distinguishes and pathogenically promotes human and murine macrophage activation syndrome. Blood. 2018;131(13):1442-55.

29. Kessel C, Fall N, Grom A, de Jager W, Vastert S, Strippoli R, et al. Definition and validation of serum biomarkers for optimal differentiation of hyperferritinaemic cytokine storm conditions in children: a retrospective cohort study. Lancet Rheumatol. 2021;3(8):E563-E73.

30. Put K, Avau A, Brisse E, Mitera T, Put S, Proost P, et al. Cytokines in systemic juvenile idiopathic arthritis and haemophagocytic lymphohistiocytosis: tipping the balance between interleukin-18 and interferon-gamma. Rheumatology (Oxford). 2015;54(8):1507-17. 
medRxiv preprint doi: https://doi.org/10.1101/2022.02.01.22270100; this version posted February 2, 2022. The copyright holder for this preprint (which was not certified by peer review) is the author/funder, who has granted medRxiv a license to display the preprint in perpetuity.

All rights reserved. No reuse allowed without permission.

31. Hinze T, Kessel C, Hinze CH, Seibert J, Gram H, Foell D. A dysregulated interleukin18-interferon-gamma-CXCL9 axis impacts treatment response to canakinumab in systemic juvenile idiopathic arthritis. Rheumatology (Oxford). 2021;60(11):5165-74.

32. Pascarella A, Bracaglia C, Caiello I, Arduini A, Moneta GM, Rossi MN, et al. Monocytes From Patients With Macrophage Activation Syndrome and Secondary Hemophagocytic Lymphohistiocytosis Are Hyperresponsive to Interferon Gamma. Front Immunol. 2021;12:663329.

33. Sikora KA, Fall N, Thornton S, Grom AA. The limited role of interferon-gamma in systemic juvenile idiopathic arthritis cannot be explained by cellular hyporesponsiveness. Arthritis Rheum. 2012;64(11):3799-808.

34. Avau A, Mitera T, Put S, Put K, Brisse E, Filtjens J, et al. Systemic juvenile idiopathic arthritis-like syndrome in mice following stimulation of the immune system with freund's complete adjuvant: Regulation by interferon- $\gamma$. Arthritis and Rheumatology. 2014;66(5):134051.

35. Malengier-Devlies B, Decaesteker T, Dekoster K, Vanstapel A, Ahmadzadeh K, Poosti F, et al. Lung Functioning and Inflammation in a Mouse Model of Systemic Juvenile Idiopathic Arthritis. Front Immunol. 2021;12:642778.

36. Hinze CH, Holzinger D, Lainka E, Haas JP, Speth F, Kallinich T, et al. Practice and consensus-based strategies in diagnosing and managing systemic juvenile idiopathic arthritis in Germany. Pediatr Rheumatol Online J. 2018;16(1):7.

37. Ravelli A, Minoia F, Davi S, Horne A, Bovis F, Pistorio A, et al. 2016 Classification Criteria for Macrophage Activation Syndrome Complicating Systemic Juvenile Idiopathic Arthritis: A European League Against Rheumatism/American College of Rheumatology/Paediatric Rheumatology International Trials Organisation Collaborative Initiative. Ann Rheum Dis. 2016;75(3):481-9. 
medRxiv preprint doi: https://doi.org/10.1101/2022.02.01.22270100; this version posted February 2, 2022. The copyright holder for this preprint (which was not certified by peer review) is the author/funder, who has granted medRxiv a license to display the preprint in perpetuity.

All rights reserved. No reuse allowed without permission.

38. Ravelli A, Minoia F, Davi S, Horne A, Bovis F, Pistorio A, et al. 2016 Classification Criteria for Macrophage Activation Syndrome Complicating Systemic Juvenile Idiopathic Arthritis: A European League Against Rheumatism/American College of Rheumatology/Paediatric Rheumatology International Trials Organisation Collaborative Initiative. Arthritis Rheumatol. 2016;68(3):566-76.

39. Park C, Miranda-Garcia M, Berendes R, Horneff G, Kuemmerle-Deschner J, Ganser G, et al. MRP8/14 serum levels as diagnostic markers for systemic juvenile idiopathic arthritis in children with prolonged fever. Rheumatology (Oxford). 2021.

40. Tian Y, Zajac AJ. IL-21 and T Cell Differentiation: Consider the Context. Trends Immunol. 2016;37(8):557-68.

41. Suto A, Wurster AL, Reiner SL, Grusby MJ. IL-21 inhibits IFN-gamma production in developing Th1 cells through the repression of eomesodermin expression. J Immunol. 2006;177(6):3721-7.

42. Crotty S. T follicular helper cell differentiation, function, and roles in disease. Immunity. 2014;41(4):529-42.

43. Bocharnikov AV, Keegan J, Wacleche VS, Cao Y, Fonseka CY, Wang G, et al. PD1hiCXCR5- T peripheral helper cells promote B cell responses in lupus via MAF and IL-21. JCI Insight. 2019;4(20).

44. Rao DA, Gurish MF, Marshall JL, Slowikowski K, Fonseka CY, Liu Y, et al. Pathologically expanded peripheral T helper cell subset drives B cells in rheumatoid arthritis. Nature. 2017;542(7639):110-4.

45. Yoshitomi H, Ueno $\mathrm{H}$. Shared and distinct roles of $\mathrm{T}$ peripheral helper and $\mathrm{T}$ follicular helper cells in human diseases. Cell Mol Immunol. 2021;18(3):523-7.

46. Mo A, Marigorta UM, Arafat D, Chan LHK, Ponder L, Jang SR, et al. Diseasespecific regulation of gene expression in a comparative analysis of juvenile idiopathic arthritis and inflammatory bowel disease. Genome Med. 2018;10(1):48. 
47. Inamo J. T peripheral helper cells signature genes in patients with rheumatoid arthritis.

Clin Rheumatol. 2020;39(6):2019-21.

48. Cano-Gamez E, Soskic B, Roumeliotis TI, So E, Smyth DJ, Baldrighi M, et al. Singlecell transcriptomics identifies an effectorness gradient shaping the response of CD4(+) T cells to cytokines. Nat Commun. 2020;11(1):1801.

49. Sanz I, Wei C, Jenks SA, Cashman KS, Tipton C, Woodruff MC, et al. Challenges and Opportunities for Consistent Classification of Human B Cell and Plasma Cell Populations. Front Immunol. 2019;10:2458.

50. Johnston RJ, Poholek AC, DiToro D, Yusuf I, Eto D, Barnett B, et al. Bcl6 and Blimp1 are reciprocal and antagonistic regulators of $\mathrm{T}$ follicular helper cell differentiation. Science. 2009;325(5943):1006-10.

51. Nurieva RI, Chung Y, Martinez GJ, Yang XO, Tanaka S, Matskevitch TD, et al. Bcl6 mediates the development of T follicular helper cells. Science. 2009;325(5943):1001-5.

52. Yu D, Rao S, Tsai LM, Lee SK, He Y, Sutcliffe EL, et al. The transcriptional repressor Bcl-6 directs $\mathrm{T}$ follicular helper cell lineage commitment. Immunity. 2009;31(3):457-68.

53. Manzo A, Vitolo B, Humby F, Caporali R, Jarrossay D, Dell'accio F, et al. Mature antigen-experienced T helper cells synthesize and secrete the B cell chemoattractant CXCL13 in the inflammatory environment of the rheumatoid joint. Arthritis Rheum. 2008;58(11):337787.

54. Hugle B, Schippers A, Fischer N, Ohl K, Denecke B, Ticconi F, et al. Transcription factor motif enrichment in whole transcriptome analysis identifies STAT4 and BCL6 as the most prominent binding motif in systemic juvenile idiopathic arthritis. Arthritis Res Ther. 2018;20(1):98.

55. Locci M, Wu JE, Arumemi F, Mikulski Z, Dahlberg C, Miller AT, et al. Erratum: Activin A programs the differentiation of human TFH cells. Nat Immunol. 2016;17(10):1235. 
medRxiv preprint doi: https://doi.org/10.1101/2022.02.01.22270100; this version posted February 2, 2022. The copyright holder for this preprint (which was not certified by peer review) is the author/funder, who has granted medRxiv a license to display the preprint in perpetuity.

All rights reserved. No reuse allowed without permission.

56. Schmitt N, Liu Y, Bentebibel SE, Munagala I, Bourdery L, Venuprasad K, et al. The cytokine TGF-beta co-opts signaling via STAT3-STAT4 to promote the differentiation of human TFH cells. Nat Immunol. 2014;15(9):856-65.

57. Schmitt N, Liu Y, Bentebibel SE, Ueno H. Molecular Mechanisms Regulating T Helper 1 versus $\mathrm{T}$ Follicular Helper Cell Differentiation in Humans. Cell Rep. 2016;16(4):1082-95.

58. Yasin S, Fall N, Brown RA, Henderlight M, Canna SW, Girard-Guyonvarc'h C, et al. IL-18 as a biomarker linking systemic juvenile idiopathic arthritis and macrophage activation syndrome. Rheumatology. 2020;59(2):361-6.

59. Sakuragi T, Yamada H, Haraguchi A, Kai K, Fukushi J, Ikemura S, et al. Autoreactivity of Peripheral Helper T Cells in the Joints of Rheumatoid Arthritis. J Immunol. 2021;206(9):2045-51.

60. Patrick AE ET, Shoaff K, Patrick DM, Flaherty DK, Graham TB, et al. JIA patient T cells differentiate into Th1, Th17 and Th1.17 effector cells under Th1 polarizing conditions. medRxiv. 2021;doi.org/10.1101/2021.10.01.21264425.

61. Hugle B, Hinze C, Lainka E, Fischer N, Haas JP. Development of positive antinuclear antibodies and rheumatoid factor in systemic juvenile idiopathic arthritis points toward an autoimmune phenotype later in the disease course. Pediatr Rheumatol Online J. 2014;12:28.

62. Long D, Chen Y, Wu H, Zhao M, Lu Q. Corrigendum to "Clinical Significance and Immunobiology of IL-21 in Autoimmunity"[J. Autoimmun. 99C (2019) p1-14]. J Autoimmun. 2020;111:102455. 
Table 1. Study participants

\begin{tabular}{|c|c|c|c|c|c|c|c|c|c|c|c|}
\hline \multirow[b]{2}{*}{ Analysis } & \multirow[b]{2}{*}{$\begin{array}{l}\text { Disease } \\
\text { status }\end{array}$} & \multirow[b]{2}{*}{$\begin{array}{c}\text { Study } \\
\text { subjects, } \\
\text { n }\end{array}$} & \multicolumn{3}{|c|}{ Demographics } & \multicolumn{3}{|c|}{ Clinical characteristics } & \multicolumn{2}{|c|}{ Laboratory parameters } & \multirow[t]{2}{*}{ Treatment,n } \\
\hline & & & $\begin{array}{l}\text { Age at } \\
\text { sampling, } \\
\text { median } \\
\text { (range) }\end{array}$ & $\begin{array}{c}\text { Sex, n } \\
\text { female/ } \\
\text { male }\end{array}$ & $\begin{array}{l}\text { Median } \\
\text { disease } \\
\text { duration } \\
\text { (range) }\end{array}$ & $\begin{array}{l}\text { No. of } \\
\text { active } \\
\text { joints } \\
\text { (range) }\end{array}$ & $\begin{array}{c}\text { fever, } \\
\mathrm{n}\end{array}$ & $\begin{array}{c}\text { rash, } \\
\mathrm{n}\end{array}$ & $\begin{array}{l}\text { Median BSR, } \\
\text { mm/h (range) }\end{array}$ & $\begin{array}{l}\text { Median CRP, } \\
\text { mg/dl (range) }\end{array}$ & \\
\hline \multirow{3}{*}{$\begin{array}{l}\text { in vitro } \mathrm{Th} 1 / \mathrm{Th} 17 \\
\text { differentiation } \\
\text { and } \\
\text { ex vivo } \\
\text { FACS }\end{array}$} & $\mathrm{HC}$ & 7 & $11(7-16)$ & $4 / 3$ & NA & NA & NA & NA & NR & NR & NA \\
\hline & $\mathrm{AD}$ & 5 & $8(6-17)$ & $3 / 2$ & $1(0.1-4)$ & $3(0-14)$ & 3 & 2 & $22(8-105)$ & $<0.5(<0.5-6.3)$ & $\begin{array}{c}\text { Toc, } 3 \\
\text { Sar, } 1 \\
\text { Pred, } 4 \\
\text { CsA, } 1 \\
\text { Tac, } 1 \\
\end{array}$ \\
\hline & ID & 9 & $9(4-22)$ & $6 / 3$ & $6(0.3-11)$ & 0 & 0 & 0 & $3(1-20)$ & $<0.5(<0.5-1.57)$ & $\begin{array}{c}\text { naive, } 2 \\
\text { Ana, } 1 \\
\text { Cana, } 3 \\
\text { Toc, } 2 \\
\text { Ada, } 1 \\
\text { Pred, } 3 \\
\text { CsA, } 1 \\
\text { MTX, } 3\end{array}$ \\
\hline \multirow{3}{*}{$\begin{array}{l}\text { in vitro } \mathrm{Th} 1 / \mathrm{Tfh} \\
\text { differentiation } \\
\text { and } \\
\text { ex vivo } \\
\text { FACS }\end{array}$} & $\mathrm{HC}$ & 5 & $12(10-22)$ & $2 / 3$ & NA & NA & NA & NA & NR & NR & NA \\
\hline & $\mathrm{AD}$ & 4 & $12(7-17)$ & $2 / 2$ & $1.2(0.2-7)$ & $1(0-8)$ & 3 & 2 & $13.5(2-55)$ & $<0.5(<0.5-6.0)$ & $\begin{array}{c}\text { naïve, } 1 \\
\text { Ana, } 2 \\
\text { Toc, } 2 \\
\text { Pred, } 2 \\
\text { CsA, } 1 \\
\text { MTX, } 1\end{array}$ \\
\hline & ID & 4 & $13.5(5-18)$ & $2 / 2$ & $1.5(0.6-2)$ & 0 & 0 & 0 & $9.5(2-12)$ & $<0.5$ & $\begin{array}{c}\text { naive, } 1 \\
\text { Ana, } 2 \\
\text { Cana, } 1 \\
\text { Pred, } 1 \\
\text { CsA, } 1 \\
\text { Tac, } 1\end{array}$ \\
\hline in vitro $\mathrm{Th} 1 / \mathrm{Tfh}$ & $\mathrm{HC}$ & 4 & $23(22-24)$ & $2 / 2$ & NA & NA & NA & NA & NR & NR & NA \\
\hline
\end{tabular}




\begin{tabular}{|c|c|c|c|c|c|c|c|c|c|c|c|}
\hline \multirow{2}{*}{$\begin{array}{l}\text { differentiation } \\
+ \\
\text { memory B cell } \\
\text { co-cultures }\end{array}$} & $\mathrm{AD}^{* *}$ & 2 & \multirow[b]{2}{*}{$13(9.0-19.0)$} & \multirow[b]{2}{*}{$2 / 3$} & \multirow[b]{2}{*}{$2.1(0.3-4.5)$} & 0 & 2 & 0 & $59 ; 19$ & $>0,5 ; 0,8$ & $\begin{array}{l}\text { Ana, } 1 \\
\text { Pred, } 2\end{array}$ \\
\hline & $\mathrm{ID}^{* *}$ & 3 & & & & 0 & 0 & 0 & $5(4-11)$ & $<0.5$ & $\begin{array}{c}\text { naive, } 1 \\
\text { Ana, } 1 \\
\text { Cana, } 1 \\
\text { CsA, } 1\end{array}$ \\
\hline \multirow{3}{*}{$\begin{array}{l}\text { ex vivo } \\
\text { cytokines }\end{array}$} & $\mathrm{HC}$ & 10 & $12(10-22)$ & $2 / 3$ & NA & NA & NA & NA & NR & NR & NA \\
\hline & $\mathrm{AD}$ & 25 & $7(0.5-18)$ & $14 / 11$ & $0.65(0-7)$ & $1(0-17)$ & NR & NR & $80(28-108)$ & $8.4(5.43-76.17)$ & $\begin{array}{c}\text { naïve, } 22 \\
\text { Ana, } 2 \\
\text { CsA, } 1\end{array}$ \\
\hline & ID & 9 & $11(6-18)$ & $6 / 3$ & $4.5(0.24-13)$ & 0 & NR & NR & $5.5(3-9)$ & $<0.5$ & $\begin{array}{c}\text { naïve, } 7 \\
\text { Ana, } 2\end{array}$ \\
\hline
\end{tabular}

\section{NA not applicable \\ NR not recorded}

Age and disease duration in years

*The same study samples were used for ex vivo flow cytometry analyses of PBMCs and isolation of Th cells for in vitro Th cell differentiation experiments and subsequent flow cytometry and cytokine bead assay

**demographics are pooled to allow for full anonymization 
A

(sJIA) Th1 conditions
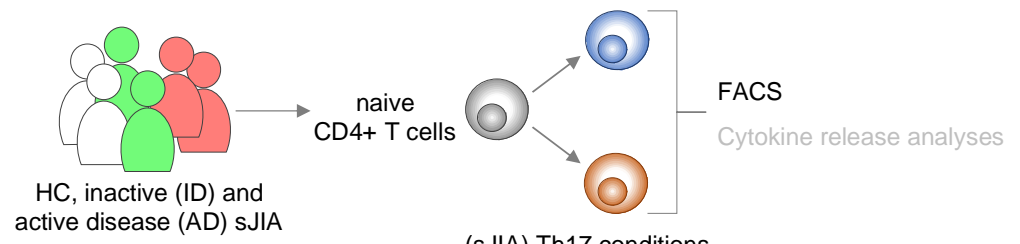

(sJIA) Th17 conditions
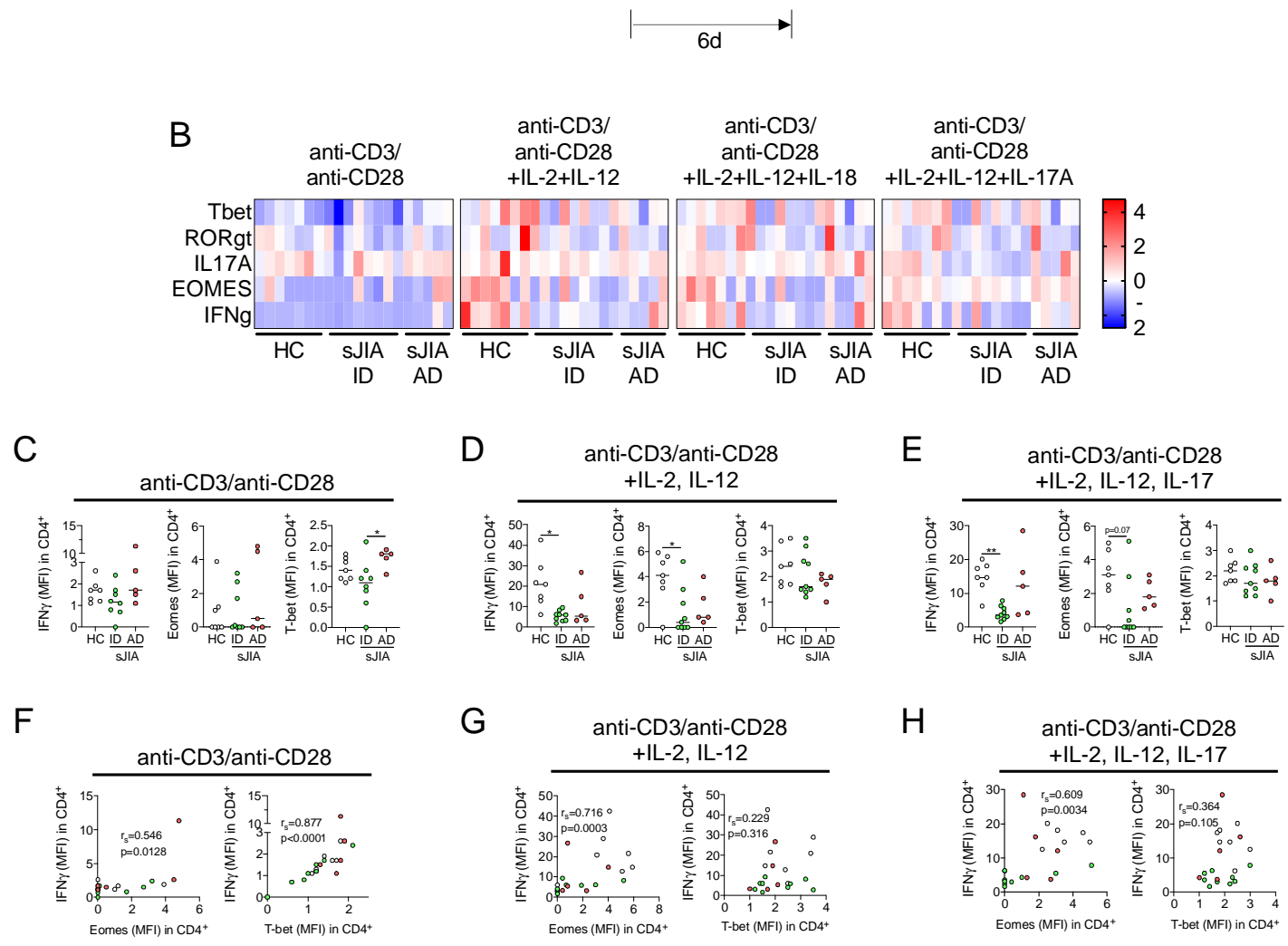

Figure 1. SJIA naïve CD4+ T helper (Th) cell differentiation towards Th1 results in low IFN $\gamma$ and Eomesodermin expression. A, Naive Th cells were isolated from pediatric healthy controls $(\mathrm{HC}, \mathrm{n}=7)$, active disease $(\mathrm{AD}, \mathrm{n}=5)$, and inactive disease (ID, $n=8)$ sJIA patients (see table 1) and cultured under T0 (anti-CD3/anti-CD28) and different Th1 and Th17 polarizing conditions. IL-17A and IL-18 were included in Th1 conditions to somewhat mimic a sJIA-cytokine milieu. Following six days of culture and super-stimulation with phorbol 12myristate 13-acetate/ionomycin (4h), cells were analyzed by flow cytometry. B, Heatmap of z-scores indicating T-bet, ROR $\gamma$ t, IL-17A, IFN $\gamma$, and Eomesodermin (Eomes) expression (geometric mean fluorescence intensity (MFI) normalized to unstimulated samples) in cells arising from the indicated culture conditions and following super-stimulation as described. C- 
medRxiv preprint doi: https://doi.org/10.1101/2022.02.01.22270100; this version posted February 2, 2022. The copyright holder for this preprint (which was not certified by peer review) is the author/funder, who has granted medRxiv a license to display the preprint in perpetuity. All rights reserved. No reuse allowed without permission.

E, IFN $\gamma$ (left panels), Eomes (center panels), and T-bet (right panels) expression (MFI), as well as (F-H) correlation of IFN $\gamma$ with Eomes (left panels) or T-bet (right panels) expression (MFI) in cells as in $\mathbf{B}$ is shown. B-H, Each data point represents a value derived from an individual patient or HC. C-E, Lines indicate median values, data were analyzed by KruskalWallis test followed by Dunn's post hoc test; $*=P<0.05$, ** $=P<0.01$. F-H, Simple linear regression (OLS) and F-test; $\mathrm{r}_{\mathrm{s}}(\mathrm{r}$-squared value) and $P$-values are indicated. 
A
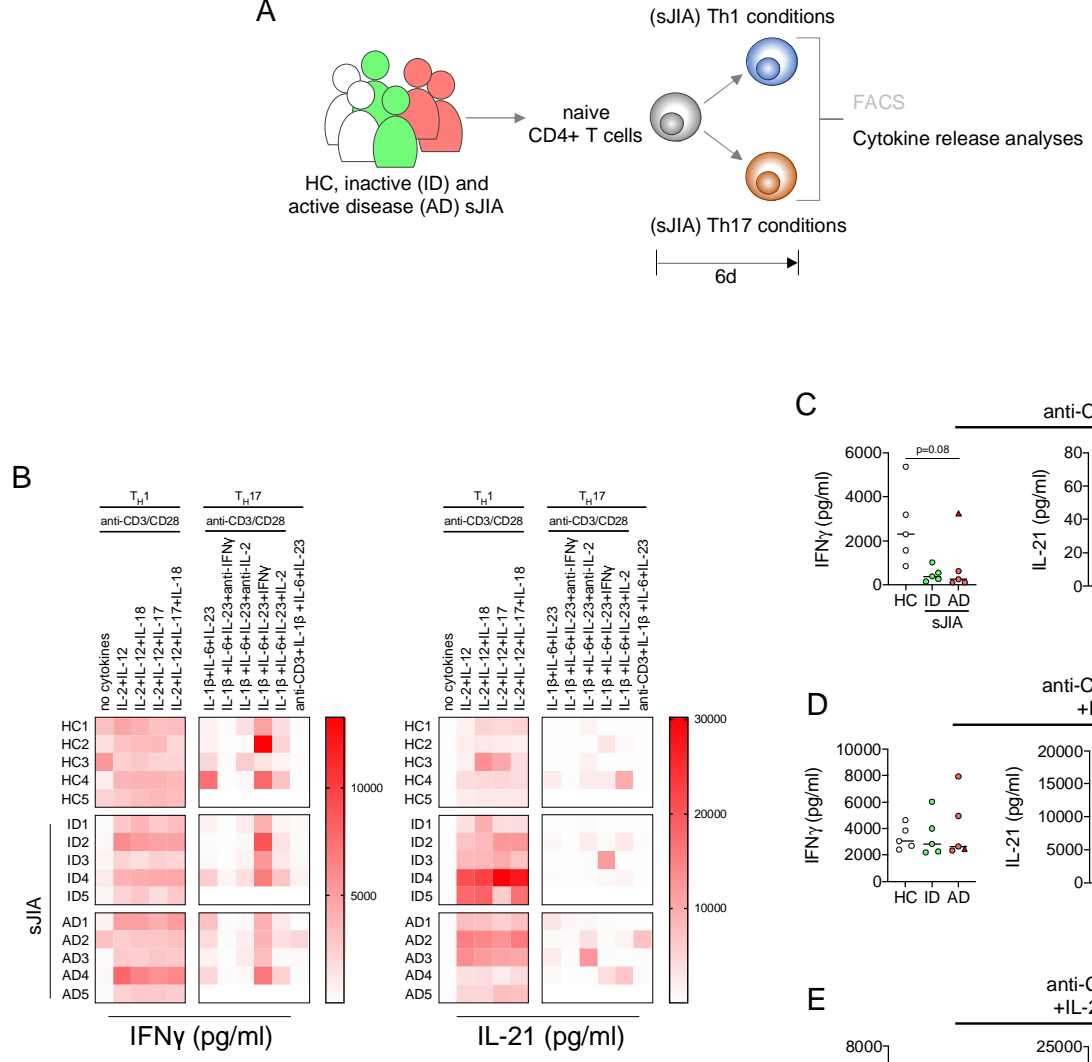

C anti-CD3/anti-CD28
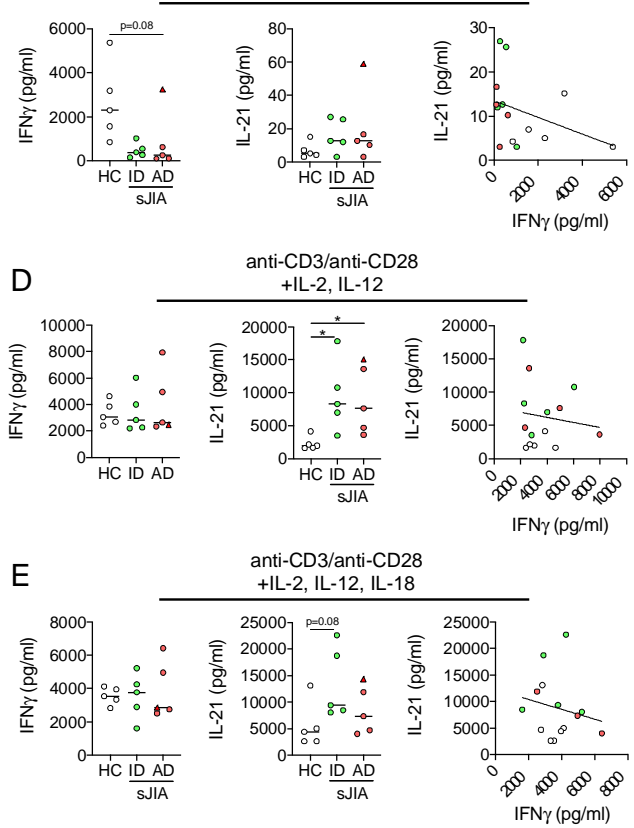

F anti-CD3/anti-CD28 $+\mathrm{IL}-2, \mathrm{IL}-12$

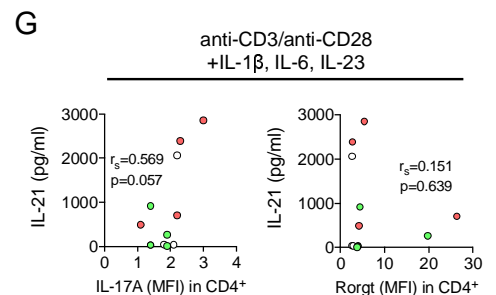

Figure 2. SJIA naïve CD4+ T helper (Th) cell differentiation towards Th1 is hallmarked by IL-21 release in negative association with IFN $\gamma$ and Eomesodermin expression. A, Naive Th cells were isolated from pediatric healthy controls $(\mathrm{HC}, \mathrm{n}=7)$, active disease $(A D, n=5)$, and inactive disease (ID, $\mathrm{n}=8$ ) sJIA patients (see table 1) and cultured under T0 (anti-CD3/antiCD28) and different Th1 and Th17 polarizing conditions. IL-17A and IL-18 were included to mimic a sJIA-cytokine milieu. On day six of culture, cytokine release (IFN $\gamma$, IL-17A, IL-21, 
IL-22) into culture supernatants following phorbol 12-myristate 13-acetate/ionomycin superstimulation was analyzed by multiplexed bead array assay. B, Heatmaps of IFN $\gamma$ (left panel) and IL-21 (right panel) release (pg/ml) by naive CD4+ cells following culture under the indicated T0, Th1, and Th17 polarizing conditions and super-stimulation as described. C-E, IFN $\gamma$ (left panels) and IL-21 (middle panels) release and IFN $\gamma$-IL-21 correlation (right panels) of naive CD4+ cells cultured under the indicated Th0 and Th1 polarizing conditions and following super-stimulation. Data is shown in scatter dot plots of the measured cytokine concentrations in $\mathrm{pg} / \mathrm{ml}$. The triangular data point refers to a patient who developed MAS subsequent to the analysis.

F, Correlations of IL-21 release (pg/ml) with intracellular IFN $\gamma$ (left panel), Eomesodermin (Eomes) (middle panel) and T-bet (right panel) expression (geometric mean fluorescence intensities (MFIs) normalized to unstimulated samples) by cells cultured under the indicated Th1 polarizing condition and super-stimulated. G, Correlation of IL-21 release (pg/ml) and intracellular IL-17A (left panel) and ROR $\gamma t$ (right panel) expression (MFI) by naïve CD4+ Th cells upon culture under the indicated Th17 polarizing condition and following superstimulation. B-G, Each data point presents a value derived from an individual patient or HC. C-E, Lines indicate median values. Data in left and middle panels were analyzed by KruskalWallis followed by Dunn's post hoc test; $*=P<0.05$. C-G, All correlation data were analyzed for simple linear regression (OLS) and F-test; $\mathrm{r}_{\mathrm{s}}$ (r-squared value) and $P$-values are indicated. 


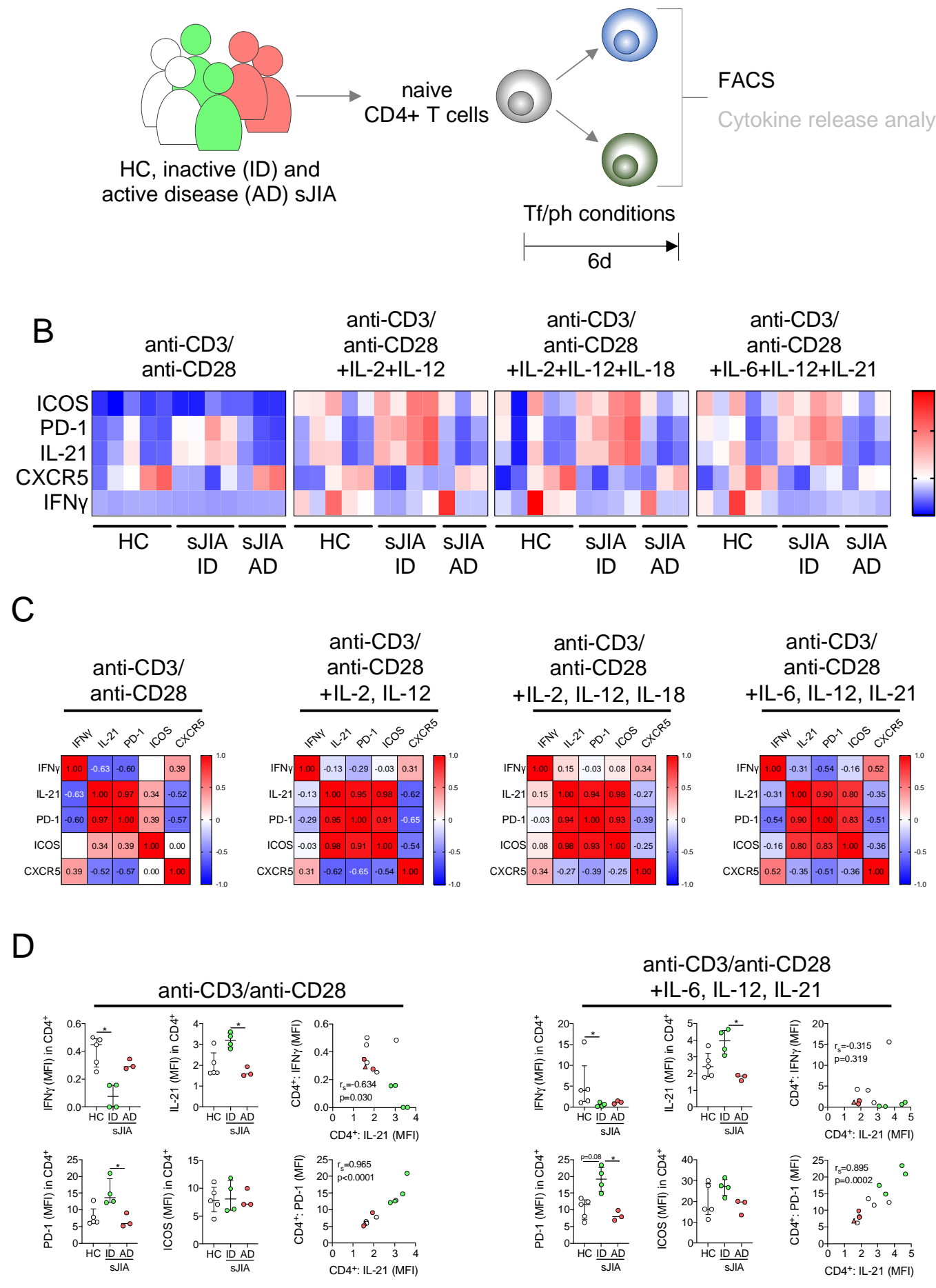

Figure 3. Early CD4+ $\mathrm{T}$ helper (Th) cell differentiation in systemic juvenile idiopathic arthritis (sJIA) is shifted toward a (PD-1+ICOS+CXCR5-) peripheral T helper (Tph) cell phenotype. A, Naïve Th cells were isolated from pediatric healthy controls ( $\mathrm{HC}, \mathrm{n}=5)$, active disease $(A D, n=3)$, and inactive disease (ID, n=4) sJIA patients (see table 1) were cultured 
under T0, Th1, and $\mathrm{T}$ follicular helper (Tfh) / peripheral $\mathrm{T}$ helper (Tf/ph) polarizing conditions. Following six days of culture and super-stimulation with phorbol 12-myristate 13acetate/ionomycin (4h), cells were analyzed by flow cytometry. B, Heatmap of z-scores indicating ICOS, PD-1, IL-21, CXCR5, and IFN $\gamma$ expression (geometric mean fluorescence intensity (MFI) normalized to unstimulated samples) by naïve CD4+ T cells arising from the indicated Th0, Th1, and Tf/ph polarizing conditions and following super-stimulation. C, Multiple correlation analyses of IFN $\gamma$, IL-21, PD-1, ICOS, and CXCR5 expression (MFI)as shown in B. Spearman's rank correlation coefficients are indicated. D, IFN $\gamma$, IL-21, PD-1, and ICOS expression (MFI, left and middle columns) and correlation of IL-21 and IFN $\gamma$ or PD-1 expression (MFI, right columns) by naïve CD4+ T cells cultured under the indicated Th0 (left panel) and Tf/ph polarizing (right panel) conditions and following super-stimulation. B-D, Each data point presents a value derived from an individual patient or HC. D, Lines indicate median values. Data in left and middle columns were analyzed by Kruskal-Wallis followed by Dunn's post hoc test; $*=P<0.05$. Correlation data were analyzed by simple linear regression (OLS) and F-test; $\mathrm{r}_{\mathrm{s}}(\mathrm{r}$-squared value) and $P$-values are indicated. 

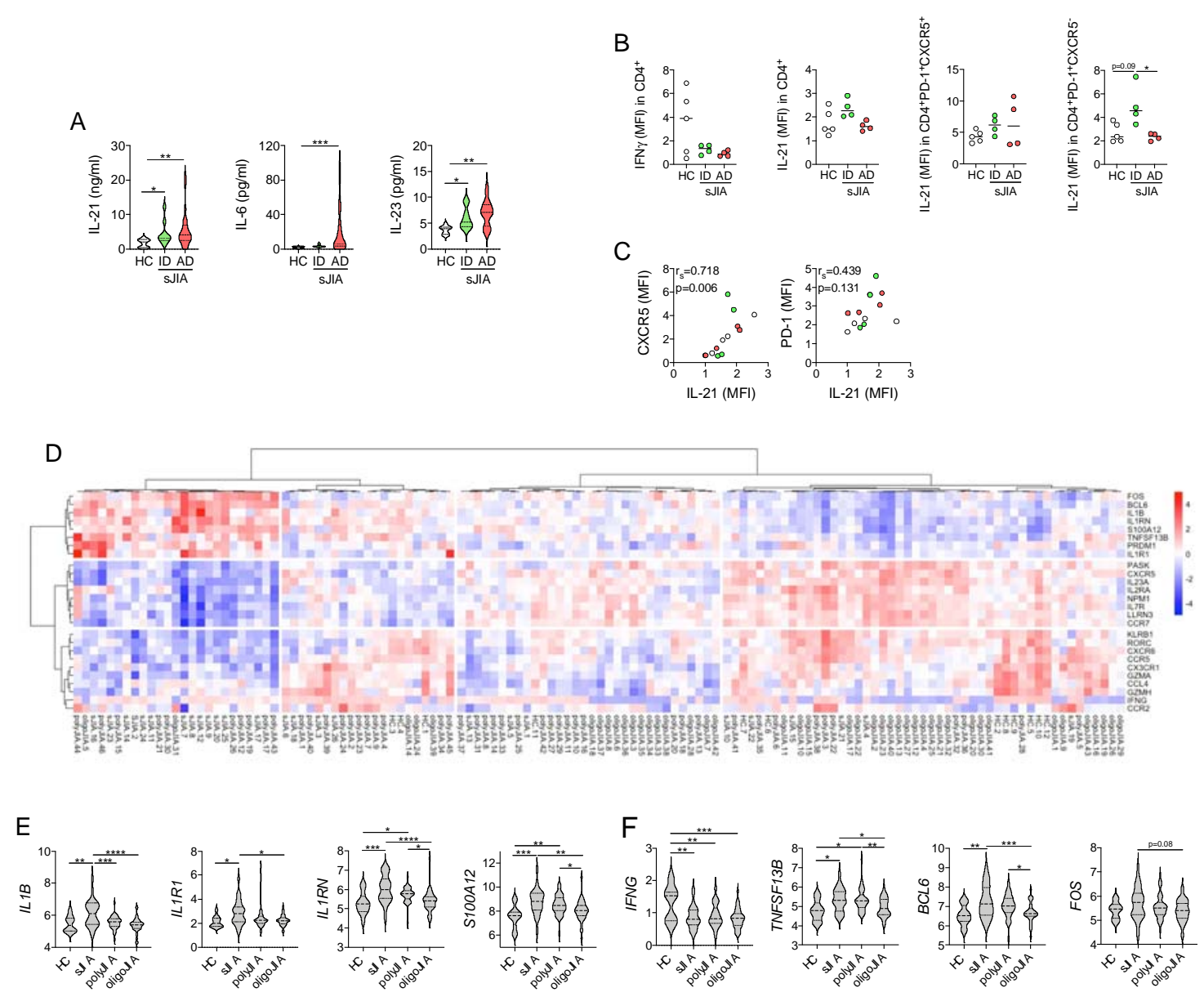

Figure 4. Circulating CD4+ $\mathrm{T}$ helper (cTh) cells in systemic juvenile idiopathic arthritis (sJIA) reveal a $\mathrm{T}$ follicular helper (Tfh) / peripheral $\mathrm{T}$ helper (Tph) cell signature. A, IL-21 (left), IL-6 (middle), and IL-23 (right) serum levels in pediatric healthy controls (HC, $\mathrm{n}=10$ ), active disease ( $A D, n=27)$, and inactive disease (ID, $n=9$ ) sJIA patients (see table 1). Data is shown in violin plots of the measured cytokine concentrations in $\mathrm{pg} / \mathrm{ml}$. B, Flow cytometry analyses of IFN $\gamma$ and IL-21 in indicated cTh cell subsets in peripheral blood mononuclear cells (PBMCs) isolated from pediatric HCs $(n=5), A D(n=3)$, and ID $(n=4)$ sJIA patients (see table 1) following super-stimulation with phorbol 12-myristate 13-acetate/ionomycin (4h). C, Correlation of IL-21 with CXCR5 (left panel) and PD-1 expression (geometric mean fluorescence intensities (MFIs) normalized to unstimulated samples, right panels) in cTh cells. D, Heatmap of unsupervised clustering using correlation distance and ward.D linkage of 
indicated gene expression in whole blood RNA sequencing data (GSE112057(46)) from HC $(n=12)$ as well as sJIA $(n=26)$, polyarticular $(n=46)$ (polyJIA) and oligoarticular JIA (oligoJIA) patients (n=43). E and $\mathbf{F}$, Expression of SJIA-hallmark genes (E, ILIB, IL1Rl, $I L 1 R N, S 100 A 12)$ as well as $(\mathbf{F})$ reported $\mathrm{T}$ cell associated genes $I F N G, T N F S F 13 B)(\mathrm{T}$ effector memory), BCL6 and FOS (Tfh) as in D depicted in violin plots as the relative difference in expression of the respective genes.

B-D, Each data point presents a value derived from an individual patient or HC. A, B, E, and F, Lines indicate median values. Data were analyzed by Kruskal-Wallis followed by Dunn's post hoc test $*=P<0.05, * *=P<0.01, * * *=P<0.001, * * * *=P<0.0001$. C, Simple linear regression (OLS) and F-test; $\mathrm{r}_{\mathrm{s}}(\mathrm{r}$-squared value) and $P$-values are indicated. 
A

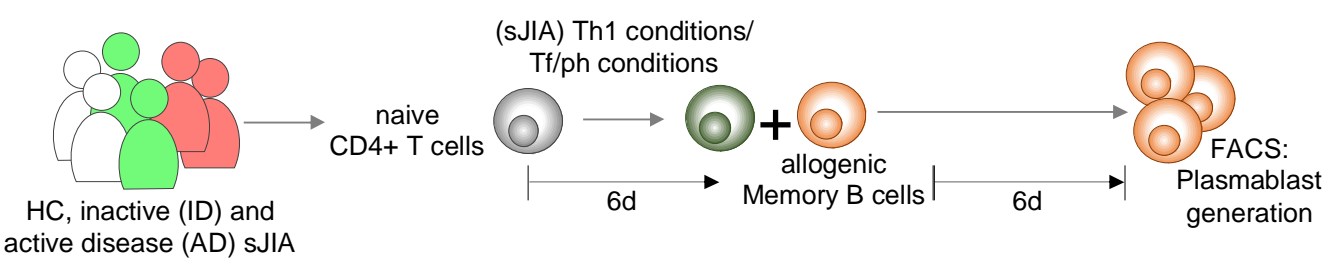

B
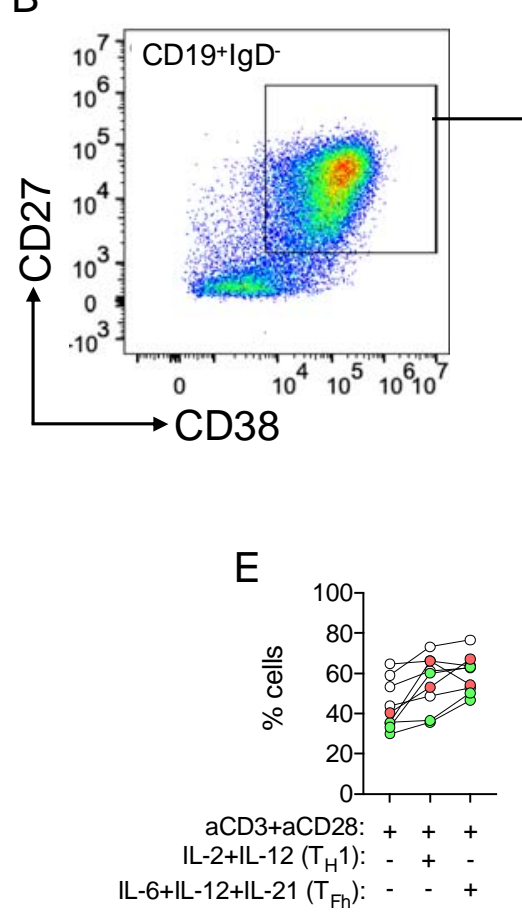

C

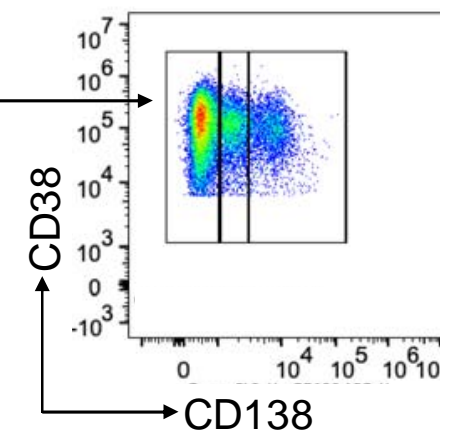

ก

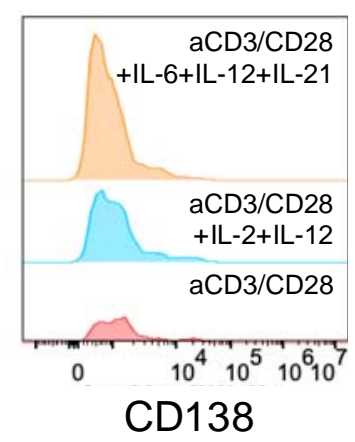

Figure 5. T follicular helper / peripheral $\mathrm{T}$ helper cells (Tf/ph) derived from sJIA naïve

CD4+ T helper (Th) cells can drive enhanced B cellular plasma blast generation. A,

Naïve Th cells were isolated from pediatric healthy controls $(H C, n=4)$, active disease (AD, $\mathrm{n}=2$ ), and inactive disease (ID, n=3) sJIA patients (see table 1) and cultured under T0, Th1, and Tf/ph polarizing conditions. Following six days of culture polarized Th cells were cocultured with allogenic HC memory B cells isolated from a single healthy donor and the generation of plasma blasts was assessed by flow cytometry following another six days of culture. B-D, Representative flow cytometry pseudo-color $(\mathbf{B}, \mathbf{C})$ or histogram plots $(\mathbf{D})$ to monitor plasma blast (CD19+IgD-CD27+CD38+CD138-) generation from co-cultured memory B cells. E, Frequency of plasma blasts in co-cultures with Th cells polarized under 
medRxiv preprint doi: https://doi.org/10.1101/2022.02.01.22270100; this version posted February 2, 2022. The copyright holder for this preprint (which was not certified by peer review) is the author/funder, who has granted medRxiv a license to display the preprint in perpetuity. All rights reserved. No reuse allowed without permission.

the indicated Th0, Th1, and Tf/ph polarizing conditions. F and G, Relative change in the frequency of plasma blasts in co-cultures with Th cells cultured under the indicated Th1 (F) and Tf/ph $(\mathbf{G})$ polarizing conditions, normalized to the Th0. E-G, Each data point presents a value derived from an individual patient or HC. F and $\mathbf{G}$, Lines indicate median values. Data were analyzed by Mann-Whitney $\mathrm{U}$ test; $*=P<0.05$. 


\section{Supplemental methods and data}

\section{Aberrant naive CD4+ T Cell differentiation in systemic juvenile idiopathic arthritis is committed to B cell help}

Julia Kuehn ${ }^{1}$, Susanne Schleifenbaum ${ }^{1}$, Antje Hellige ${ }^{1}$, Carolin Park ${ }^{1}$, Claas Hinze ${ }^{1}$, Helmut Wittkowski ${ }^{1}$, Dirk Holzinger ${ }^{2}$, Dirk Foell ${ }^{1}$ and Christoph Kessel ${ }^{1}$

${ }^{1}$ Pediatric Rheumatology \& Immunology, University Children's Hospital, Muenster, Germany

${ }^{2}$ Department of Pediatric Hematology-Oncology University of Duisburg-Essen, Essen, Germany

Corresponding author: Dr. Christoph Kessel, Department of Pediatric Rheumatology and Immunology, University Children's Hospital Muenster, Domagkstr. 3, 48149 Muenster, Germany; Email: christoph.kessel@uni-muenster.de; Phone: +49-251-83-58176; Fax: +49$251-83-58174$ 
medRxiv preprint doi: https://doi.org/10.1101/2022.02.01.22270100; this version posted February 2, 2022. The copyright holder for this preprint (which was not certified by peer review) is the author/funder, who has granted medRxiv a license to display the preprint in perpetuity.

All rights reserved. No reuse allowed without permission.

\section{Supplementary methods}

Human peripheral blood mononuclear cell (PBMC) isolation

PBMCs were isolated by density-gradient centrifugation (Pancoll, density: $1.077 \mathrm{~g} / \mathrm{ml}$, PANBiotech GmbH, Germany) from peripheral blood samples collected from sJIA patients and pediatric HCs or residual blood obtained from adult healthy thrombocyte donors. Until further assessment, the cells were frozen at $-150{ }^{\circ} \mathrm{C}$ in $10 \%$ dimethyl sulfoxide (DMSO; Carl Roth $\mathrm{GmbH}+\mathrm{Co} . \mathrm{KG}$, Germany) $/ 90 \%$ fetal calf serum $\left(\mathrm{FCS} ; \mathrm{Gibco}^{\mathrm{TM}}\right.$, Thermo Fisher Scientific Inc., Waltham, MA, USA) at $1 \times 10^{7}$ cells $\times \mathrm{ml}^{-1}$. For analysis, the PBMCs were thawed in RPMI 1640 medium supplemented with $10 \mathrm{U}$ Penicillin / $0.1 \mathrm{mg} \mathrm{x} \mathrm{ml}^{-1}$ Streptomycin, $2 \mathrm{mM}$ L-glutamine, $1 \mathrm{x}$ non-essential amino acids, $1 \mathrm{mM}$ sodium pyruvate (all purchased from Merck KGaA, Germany), and $10 \%$ FCS. The PBMCs obtained from one study sample were used for both an ad-hoc flow cytometry analysis of Th cell markers at aliquots of $1 \times 10^{5}$ cells per sample, and for the isolation of naïve Th cells for an in vitro characterization of Th cell differentiation.

Isolation, culture, and stimulation of naïve Thelper (Th) cells

Naïve Th cells were isolated from PBMCs by immunomagnetic negative selection using the EasySep $^{\mathrm{TM}}$ Human Naïve CD4+ T Cell Isolation Kit II (STEMCELL Technologies Inc., Cologne, Germany) according to the manufacturer's instruction. Naïve Th cells were diluted to $5 \times 10^{5}$ cells $\times \mathrm{ml}^{-1}$ in supplemented RPMI 1640 medium and plated at a density of $5 \times 10^{4}$ cells / well in 96-well U-bottom suspension culture plates (Greiner Bio-One, Frickenhausen, Germany) coated with $\alpha$-human CD3 (5 $\mu \mathrm{g} \mathrm{x} \mathrm{ml}^{-1}$, clone: OKT3, BioLegend, San Diego, CA, USA). Cells were differentiated for 6 days $\left(37^{\circ} \mathrm{C}, 5 \% \mathrm{CO}_{2}\right)$ in the presence of combinations of the following cytokines, stimuli, or blocking agents, as indicated and detailed in the respective results: $\alpha$-human CD28 (2.5 $\mu \mathrm{g} \mathrm{x} \mathrm{ml}^{-1}$, clone: CD28.2, BioLegend), $\alpha$-human IFN $\gamma$ (1 $\mu \mathrm{g} \mathrm{x} \mathrm{ml}{ }^{-1}$, clone: NIB42, Thermo Fisher Scientific Inc.), $\alpha$-human IL-2 (10 $\mu \mathrm{g} \mathrm{x} \mathrm{ml}{ }^{-1}$, 
clone: MQ1-17H12, BioLegend,), recombinant human IFN $\gamma$ (1000 $\mathrm{U} \mathrm{x} \mathrm{ml}^{-1}$, PeproTech, Hamburg, Germany), recombinant human IL-1 $\beta$ (50 ng x ml${ }^{-1}$, BioLegend), recombinant human IL-2 (100 U x ml${ }^{-1}$, PeproTech), recombinant human IL-6 (5 ng x ml${ }^{-1}$, PeproTech), recombinant human IL-12 (5 $\mathrm{ng} \mathrm{x} \mathrm{ml}^{-1}$, PeproTech), recombinant human IL-17A (10 ng x ml ${ }^{1}$, BioLegend), recombinant human IL-18 (5 ng x ml${ }^{-1}$, Invivogen, San Diego, CA, USA), recombinant human IL-21 (10 $\mathrm{ng} \mathrm{x} \mathrm{ml}^{-1}$, BioLegend), and recombinant human IL-23 (50 ng x $\mathrm{ml}^{-1}$, BioLegend).

\section{Co-cultures of Th cells and allogenic memory B cell}

Co-cultures were set up as described recently(43). Naïve Th cells were isolated from PBMCs and cultured for six days at conditions indicated in the present study and according to methods and concentrations as described above. Following six days of culture cells were harvested, washed twice with cell culture medium (RPMI), and were counted. Memory B cells were isolated from PBMCs obtained from a single healthy donor using the EasySepTM Human Memory B Cell Isolation Kit (STEMCELL Technologies Inc.) according to the manufacturer's instructions. Polarized T cells and isolated memory B cells were co-cultured at a 1:10 ratio (range of $\mathrm{T}$ cells numbers used in cultures: 2800-13000) in the presence of recombinant Staphylococcus aureus enterotoxin B (1 $\mu \mathrm{g} \times \mathrm{ml}^{-1}$, Hoelzel Diagnostika,

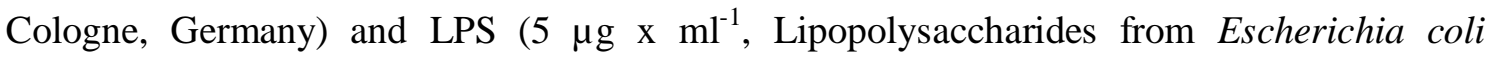
O55:B5, Sigma-Aldrich, Taufkirchen, Germany). Following six days of co-culture $\left(37^{\circ} \mathrm{C}, 5 \%\right.$ $\mathrm{CO}_{2}$ ), the cells were harvested, washed, and prepared for flow cytometry staining.

\section{Flow cytometry}

Before flow cytometry analysis, PBMCs and Th cells were stimulated by incubation with phorbol 12-myristate 13-acetate (PMA) and ionomycin (eBioscience ${ }^{\mathrm{TM}}$ Invitrogen $^{\mathrm{TM}}$ Cell Stimulation Cocktail, Thermo Fisher Scientific Inc.) in the presence of Brefeldin A and 
medRxiv preprint doi: https://doi.org/10.1101/2022.02.01.22270100; this version posted February 2, 2022. The copyright holder for this preprint (which was not certified by peer review) is the author/funder, who has granted medRxiv a license to display the preprint in perpetuity.

All rights reserved. No reuse allowed without permission.

Monensin (eBioscience ${ }^{\mathrm{TM}}$ Invitrogen ${ }^{\mathrm{TM}}$ Protein Transport Inhibitor Cocktail, Thermo Fisher Scientific Inc.) for 5 hours at $37^{\circ} \mathrm{C}$, or left unstimulated. For cell surface marker staining, $1 \times 10^{5}$ cells were incubated with the respective antibody at a concentration of $1 \mu 1 / 100 \mu 1$ sample in a buffer containing 1 x phosphate-buffered saline (PBS; Merck KGaA, Darmstadt, Germany), $0.1 \%$ bovine serum albumin (BSA; Carl Roth GmbH, Karlsruhe, Germany), 2 $\mathrm{mM}$ ethylenediaminetetraacetic acid (EDTA; Carl Roth $\mathrm{GmbH})$, and $0.05 \%$ sodium azide (Merck KGaA) for 30 minutes at $4{ }^{\circ} \mathrm{C}$ in the dark.

The following antibodies were used for T cell surface marker staining: $\alpha$-human CD3-APCCy7 (clone: OKT3, BioLegend), $\alpha$-human CD4-APC (clone: OKT4, BioLegend), $\alpha$-human CD4-BV510 (clone: OKT4, BioLegend), a-human CD161-PE-Dazzle (clone: HP-3G10, BioLegend), $\alpha$-human CD183/CXCR3-APC-Cy7 (clone: G025H7, BioLegend), $\alpha$-human CD185/CXCR5-PE-Dazzle (clone: J252D4, BioLegend), $\alpha$-human CD196/CCR6-BV650 (clone: G034E3, BioLegend), a-human CD278/ICOS-FITC (clone: C398.4A, BioLegend), and $\alpha$-human CD279/PD-1-BV650 (clone: EH12.2H7, BioLegend).

The following antibodies were used for B cellular plasmablast surface marker staining: CD19PE-CF594 (clone: HIB19, BioLegend), CD20-FITC (clone: 2H7, BioLegend), CD27-PEFire780 (PC7, clone: O323, BioLegend), CD38-BV421 (PB450, clone: HB-7, BioLegend), CD138-APC (clone: DL-101, BioLegend), and IgD-AF7000 (APC-A700, clone: IA6-2, BioLegend).

For the subsequent staining of intracellular cytokines and transcription factors, the cells were fixed and permeabilized by incubation in FixPerm Buffer (eBioscience $^{\mathrm{TM}}$ Fixation/Permeabilization Concentrate, eBiosciene ${ }^{\mathrm{TM}}$ Fixation/Permeabilization Diluent, Thermo Fisher Scientific Inc., USA) for 30 minutes at room temperature. For intracellular staining, $1 \times 10^{5}$ cells were incubated with the respective antibody at a concentration of $1 \mu 1 /$ $100 \mu$ sample in $1 \times$ Permeabilization Buffer (eBioscience ${ }^{\mathrm{TM}}$, Thermo Fisher Scientific Inc., USA) for 30 minutes at $4{ }^{\circ} \mathrm{C}$ in the dark. The following antibodies were used for intracellular 
medRxiv preprint doi: https://doi.org/10.1101/2022.02.01.22270100; this version posted February 2, 2022. The copyright holder for this preprint (which was not certified by peer review) is the author/funder, who has granted medRxiv a license to display the preprint in perpetuity.

All rights reserved. No reuse allowed without permission.

staining: $\alpha$-human Eomesodermin (EOMES)-PE-Cy7 (clone: WD1928, Thermo Fisher Scientific Inc., USA), $\alpha$-human IFN $\gamma$-BV421 (clone: 4S.B3, BioLegend, USA), $\alpha$-human IL17A-PE (clone: BL168, BioLegend, USA), $\alpha$-human IL-21-PE (clone: 3A3-N2, BioLegend, USA), $\alpha$-human ROR $\gamma$ t-APC (clone: AFKJS-9, Thermo Fisher Scientific Inc., USA), and $\alpha$ human T-bet-AF488 (clone: 4B10, BioLegend, USA). Fluorescence intensities were measured with CytoFLEX S (Beckman Coulter, USA). For compensation and gating, fluorescent beads and unstained samples were used, respectively. Measurement settings were not changed throughout the study. Cytometric data were analyzed by FlowJo (version: v10.0.8, Becton, Dickinson and Company, USA). Expression levels of cytokines and transcription factors were assessed as geometric mean fluorescence intensities (MFIs). MFIs were normalized to unstained samples, and in a second step, to control differentiation conditions ( $\alpha-\mathrm{CD} 3$ or $\alpha-\mathrm{CD} 3$ and $\alpha-\mathrm{CD} 28$ only).

\section{Multiplexed bead array assays}

Reagents for multiplexed quantification of CXCL13, IFN $\gamma$, IL-17A, IL-21, and IL-22 in supernatants of the Th cell cultures as well as of IL-6, IL-21, and IL-23 in sera were purchased from R\&D Systems (Minneapolis, OH, USA). Reagents and sera or cell culture supernatants were prepared according to the manufacturer's instructions (R\&D Systems). Data acquisition and analysis were performed on a MAGPIX instrument (Merck Millipore, Darmstadt, Germany) using xPONENT v4.2 software (Luminex).

\section{$\gamma \delta T$ cell-monocyte co-cultures}

Co-cultures of $\gamma \delta \mathrm{T}$ cells and monocytes were set up as described previously(18). Briefly, HC $\gamma \delta \mathrm{T}$ cells were isolated from PBMCs prepared from residual blood obtained from thrombocyte donors by immunomagnetic negative selection using the EasySep ${ }^{\mathrm{TM}}$ Human $\gamma / \delta$

T Cell Isolation Kit (STEMCELL Technologies Inc.) according to the manufacturer's 
medRxiv preprint doi: https://doi.org/10.1101/2022.02.01.22270100; this version posted February 2, 2022. The copyright holder for this preprint (which was not certified by peer review) is the author/funder, who has granted medRxiv a license to display the preprint in perpetuity.

All rights reserved. No reuse allowed without permission.

instructions. Monocytes were prepared from fresh $\mathrm{HC}$ whole blood using the EasySep ${ }^{\mathrm{TM}}$ Human Monocyte Isolation Kit (STEMCELL Technologies Inc.) according to the manufacturer's instructions. $\gamma \delta \mathrm{T}$ cells and monocytes were co-cultured at a ratio of $1: 2 \mathrm{in}$ RPMI 1640 medium supplemented with the phosphoantigen isopentenyl pyrophosphate (IPP; $10 \mu \mathrm{g} \mathrm{x} \mathrm{ml}^{-1}$; Merck KGaA), or the nitrogen-containing bisphosphonates zoledronate $(1 \mu \mathrm{M} \mathrm{x}$ $\mathrm{ml}^{-1}$, Sigma-Aldrich) for six days. In case of stimulations with zoledronate, monocytes were cultured with the indicated concentration for 2 hours, then were washed twice with RPMI, and subsequently co-cultured with $\gamma \delta$ T cells. All co-cultures were supplemented with recombinant human IL-2 (100 $\mathrm{U} \mathrm{x} \mathrm{ml}^{-1}$, PeproTech) and further stimulated with indicated combinations of recombinant human IL-1 $\beta$ (50 ng x ml ${ }^{-1}$, BioLegend), recombinant human IL-18 (5 ng x ml ${ }^{-1}$, Invivogen), and recombinant human IL-23 (50 $\mathrm{ng} \mathrm{x} \mathrm{ml}^{-1}$, BioLegend), as well as anti-human IFN $\gamma\left(1 \mu \mathrm{g} \mathrm{x} \mathrm{ml}^{-1}\right.$, clone: NIB42, Thermo Fisher Scientific Inc.),

\section{ELISA}

IFN $\gamma$ release by healthy donor Th cells in experiments $+/$ - recombinant IL-21, as well as IFN $\gamma$ concentration and IL-17A release in $\gamma \delta \mathrm{T}$ cell-monocyte co-cultures, were determined by ELISA. Cell culture supernatants following six days of culture in the indicated conditions and super-stimulation with phorbol 12-myristate 13-acetate/ionomycin were collected after centrifugation and frozen at $-20^{\circ} \mathrm{C}$ until analysis. For quantification of the IFN $\gamma$ and IL-17A concentrations in the supernatants, ELISA MAX ${ }^{\mathrm{TM}}$ kits (BioLegend) were used according to the manufacturer's instructions. Quantification was performed in Nunc ${ }^{\mathrm{TM}}$ 96-well polypropylene microplates (Thermo Fisher Scientific Inc.). The plates were washed with a buffer containing $140 \mathrm{mM} \mathrm{NaCl}, 4 \mathrm{mM} \mathrm{KH}_{2} \mathrm{PO}_{4}, 12 \mathrm{mM} \mathrm{Na}_{2} \mathrm{HPO}_{4}$ x $2 \mathrm{H}_{2} \mathrm{O}$, and $0.04 \%$ (v/v) Tween ${ }^{\circledR} 20$. Per sample, the assay was performed in 2 technical replicates, of which the mean IFN $\gamma$ and IL-17A concentrations were calculated. 


\section{Statistical analyses}

For statistical analyses, the statistics software GraphPad Prism for Mac OS X was used (version 6.0f, GraphPad Software Inc., USA). To test for a linear correlation between the expression of cell surface markers, transcription factors, and cytokines in restimulated PBMCs and Th cells, a simple linear regression model was fit to the data using the OLS method. If a significant association was found using an F test, the r-squared value $\left(\mathrm{r}_{\mathrm{s}}\right)$ and the p-value are indicated. To analyze the ELISA and cytokine beads assay results, a non-linear $\log -\log$ fit of baseline-corrected standard values was applied, and assayed sample values were interpolated from the respective standard curve. To compare median cytokine concentration in patient serum samples and the supernatant of distinct Th cell and $\gamma \delta \mathrm{T}$ cell differentiation conditions, Kruskal-Wallis-test and post hoc Dunn's test for nonparametric data were used since all the samples did not pass D'Agostino and Pearson normality test and/or respective skewness was $>|1|$. Similarly, to compare the median or geometric mean expression of cell surface markers, transcription factors, and cytokines in restimulated PBMCs, Th cells, and $\gamma \delta$ T cells, Kruskal-Wallis-test and post hoc Dunn's test were employed. To compare the median cytokine concentration in the supernatant of two distinct differentiation conditions, the MannWhitney U test was employed. Where statistically significant differences were observed, pvalues are indicated as follows: $* \mathrm{P}<0.05$; ** $\mathrm{P}<0.01$; *** $\mathrm{P}<0.001$, **** $\mathrm{P}<0.0001$. Corrected $\mathrm{P} \quad<\quad 0.05$ was considered statistically significant. 


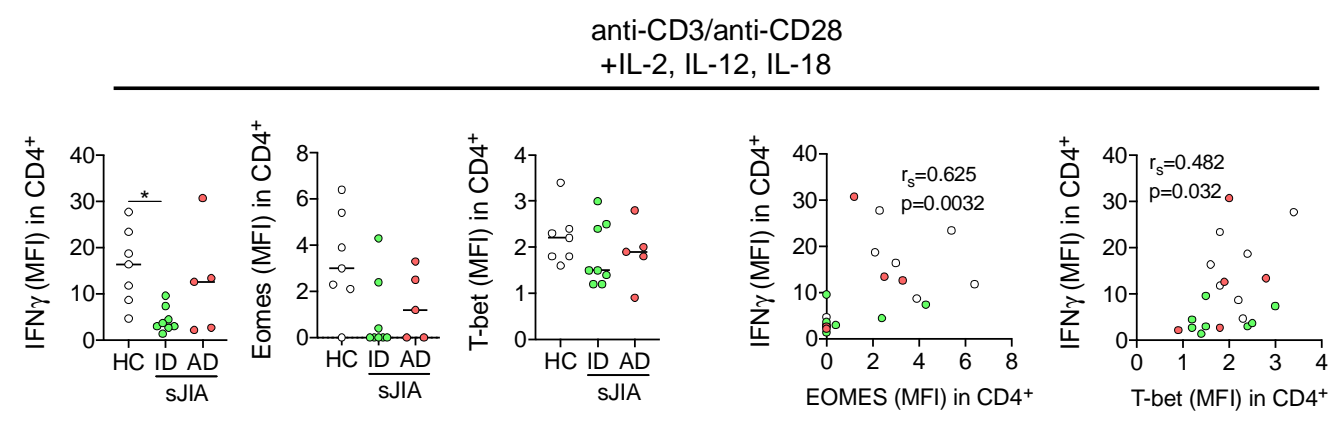

Figure S1. SJIA naïve CD4+ T helper (Th) cell differentiation towards Th1 results in low IFN $\gamma$ and Eomesodermin expression. Naive Th cells were isolated from pediatric healthy controls $(\mathrm{HC}, \mathrm{n}=7)$, active disease $(\mathrm{AD}, \mathrm{n}=5)$, and inactive disease (ID, $n=8)$ sJIA patients (see table 1) and cultured under T0 (anti-CD3/anti-CD28) and different Th1 and Th17 polarizing conditions. Following six days of culture and super-stimulation with phorbol 12myristate 13-acetate/ionomycin (4h), cells were analyzed by flow cytometry (see Figure 1). IFN $\gamma$, Eomes, and T-bet expression (geometric mean fluorescence intensity (MFI) normalized to unstimulated samples), as well as correlation of IFN $\gamma$ with Eomes or T-bet expression (MFI) in cells cultured under indicated conditions. Each data point represents a value derived from an individual patient or HC. Lines in scatter plots indicate median values, data were analyzed by Kruskal-Wallis test followed by Dunn's post hoc test; $*=P<0.05$. Correlation data were analyzed by simple linear regression (OLS) and F-test; $\mathrm{r}_{\mathrm{s}}$ (r-squared value) and $P$ values are indicated. 
A
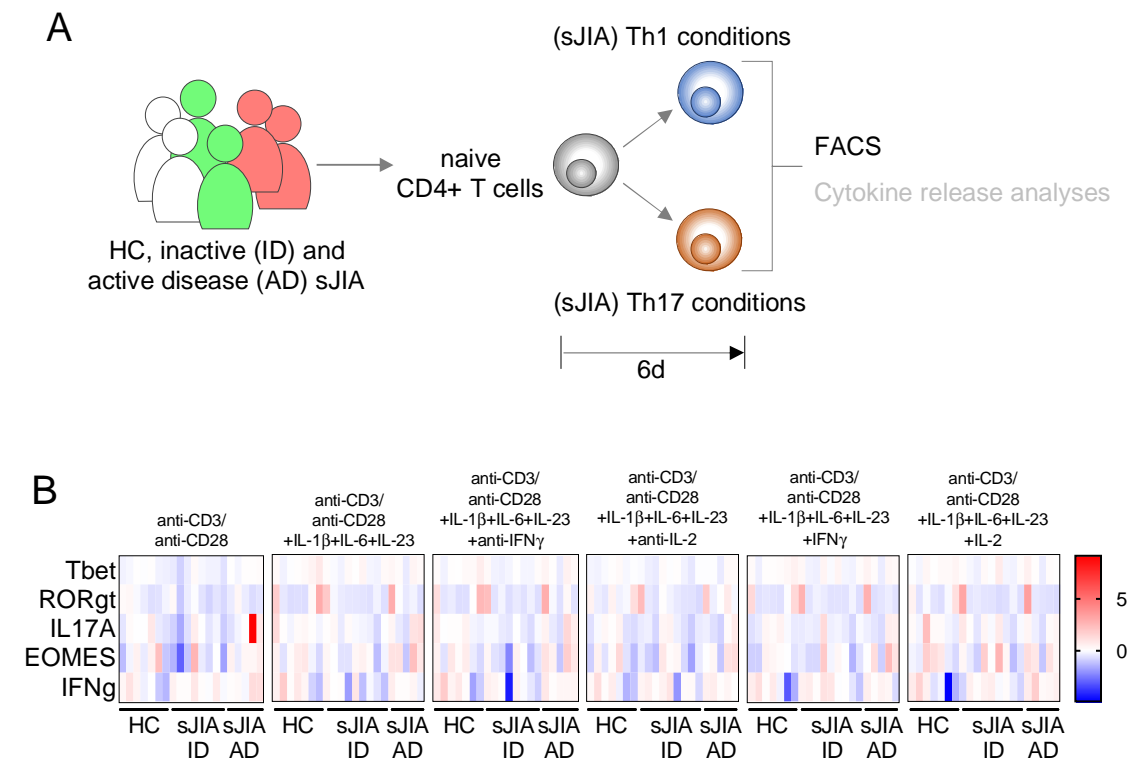

C
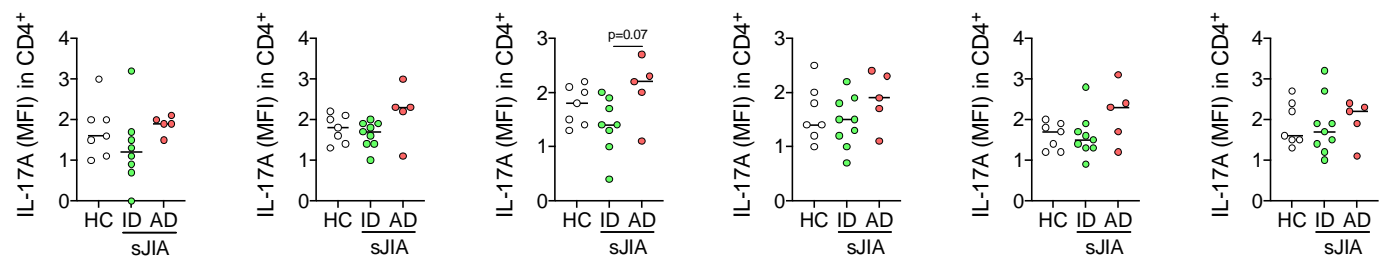

Figure S2. SJIA naïve CD4+ T helper $(\mathrm{Th})$ cell differentiation is not skewed toward a $\mathrm{T}_{\mathrm{h}} 17$ fate or high IL-17A expression. A, Naive Th cells were isolated from pediatric healthy controls $(\mathrm{HC}, \mathrm{n}=7)$, active disease $(\mathrm{AD}, \mathrm{n}=5)$, and inactive disease (ID, $n=8)$ sJIA patients (see table 1) and cultured under T0 (anti-CD3/anti-CD28) and different Th17 polarizing conditions. Following six days of culture and super-stimulation with phorbol 12-myristate 13acetate/ionomycin (4h), cells were analyzed by flow cytometry. B, Heatmap of z-scores indicating T-bet, ROR $\gamma$ t, IL-17A, IFN $\gamma$, and Eomesodermin (Eomes) expression (geometric mean fluorescence intensity (MFI) normalized to unstimulated samples) in cells arising from the indicated culture conditions and following super-stimulation as described. C, IL-17A expression (MFI) in cells as in $\mathbf{B}$ is shown. $\mathbf{B}$ and $\mathbf{C}$, Each data point represents a value derived from an individual patient or HC. C, Lines in scattered dot plots indicate median values, data were analyzed by Kruskal-Wallis test followed by Dunn's post hoc test. 


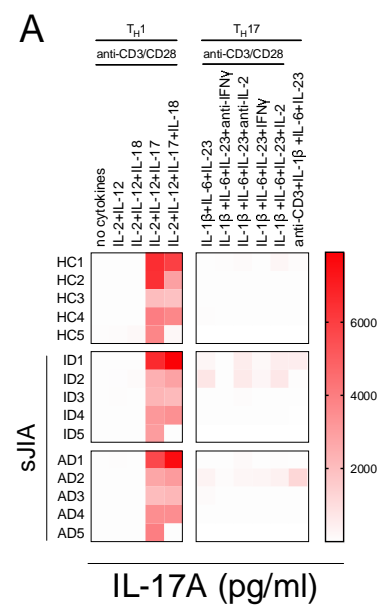

$\mathrm{B}$

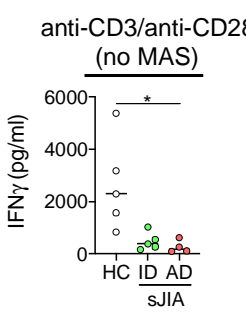

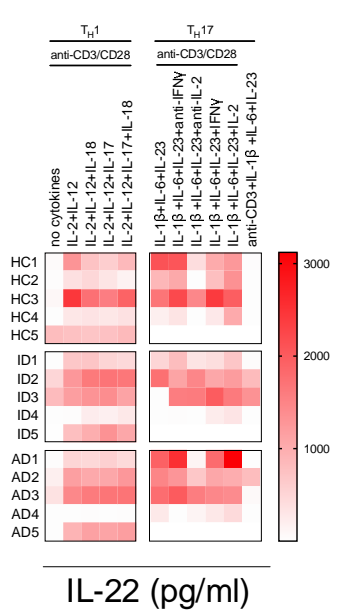

C

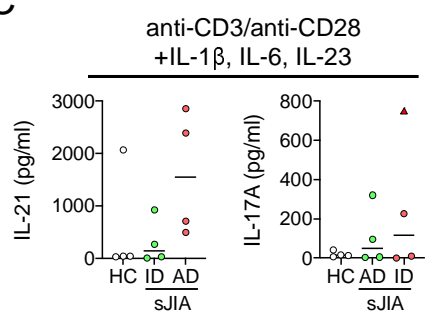

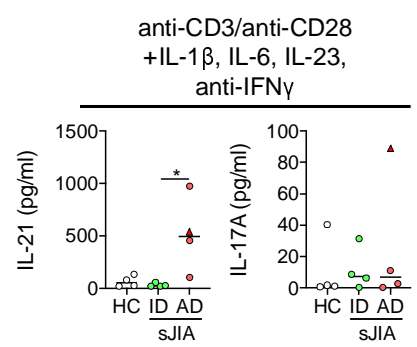

Figure S3. Developing CD4+ T helper type $1\left(\mathrm{~T}_{\mathrm{h}} 1\right)$ and type $17\left(\mathrm{~T}_{\mathrm{h}} 17\right)$ cells in systemic juvenile idiopathic arthritis (sJIA) do not release elevated levels of IL-17A or IL-22. A-C, Naive Th cells were isolated from pediatric healthy controls $(\mathrm{HC}, \mathrm{n}=7)$, active disease (AD, $\mathrm{n}=5$ ), and inactive disease (ID, n=8) sJIA patients (see table 1) and cultured under T0 (antiCD3/anti-CD28) and different Th1 and Th17 polarizing conditions as indicated. On day six of culture, cytokine release (IFN $\gamma$, IL-17A, IL-21, IL-22) into culture supernatants following phorbol 12-myristate 13-acetate/ionomycin super-stimulation was analyzed by multiplexed bead array assay. A, Heatmaps of IL-17A (left panel) and IL-22 (right panel) release (pg/ml) by naive CD4+ cells following culture under the indicated T0, Th1, and Th17 polarizing conditions and super-stimulation as described. B, IFN $\gamma$ release following Th0 polarization and super-stimulation with one patient developing MAS subsequent to the analyses excluded from the data set. C, IL-21 (left panels) and IL-17A (right panels) release by naive CD4+ cells cultured under the indicated Th17 polarizing conditions and following super-stimulation. Data 
medRxiv preprint doi: https://doi.org/10.1101/2022.02.01.22270100; this version posted February 2, 2022. The copyright holder for this preprint

(which was not certified by peer review) is the author/funder, who has granted medRxiv a license to display the preprint in perpetuity.

All rights reserved. No reuse allowed without permission.

is shown in scatter dot plots of the measured cytokine concentrations in $\mathrm{pg} / \mathrm{ml}$. A-C, Each data point presents a value derived from an individual patient or HC. $\mathbf{B}$ and $\mathbf{C}$, Lines indicate median values. Data were analyzed by Kruskal-Wallis followed by Dunn's post hoc test; * = $P<0.05$. 

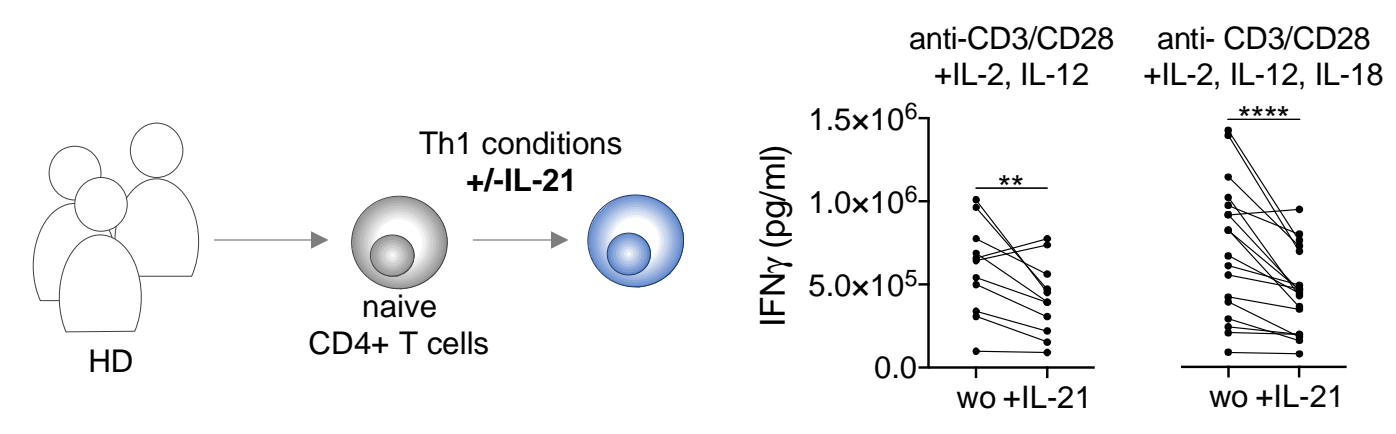

Figure S4. IL-21 restricts IFN $\gamma$ release by developing CD4+ T helper type 1 (Th1) cells derived from naïve adult healthy donor CD4+ T cells. Naïve Th cells were isolated from adult healthy donors (HD, $\mathrm{n}=18)$ and cultured under Th1 polarizing conditions in the absence or presence of recombinant human IL-21. IL-18 was included to somewhat mimic the sJIAcytokine environment. On day six of culture, IFN $\gamma$ release into culture supernatants following phorbol 12-myristate 13-acetate/ionomycin super-stimulation was analyzed by ELISA. Scatter dot plots show IFN $\gamma$ release in $\mathrm{pg} / \mathrm{ml}$ by naive HC CD4+ cells cultured under the indicated Th1 polarizing conditions (left: $\mathrm{n}=11$, right: $\mathrm{n}=18$ ) in the absence (wo) and presence (+IL-21) of IL-21 and following super-stimulation as described. Each data point presents a value derived from an individual HD and data were analyzed by Wilcoxon signed-rank test; $* *=P<0.01, * * * *=P<0.0001$. 


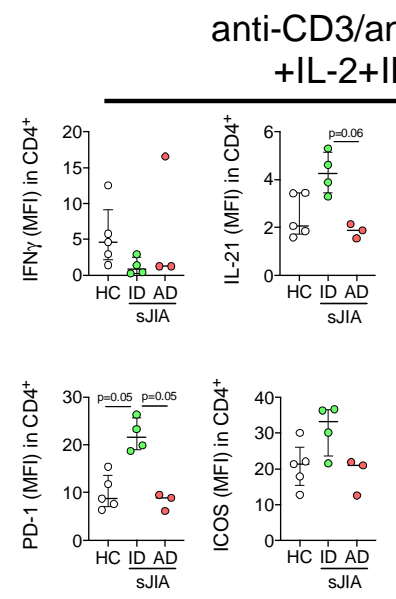

ti-CD28
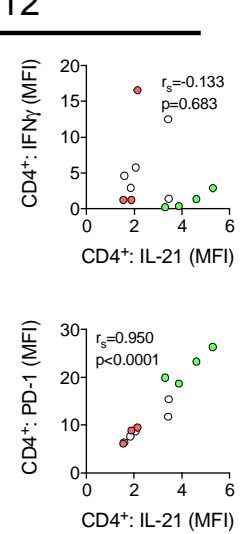

anti-CD3/anti-CD28

$+\mathrm{IL}-2, \mathrm{IL}-12, \mathrm{IL}-18$
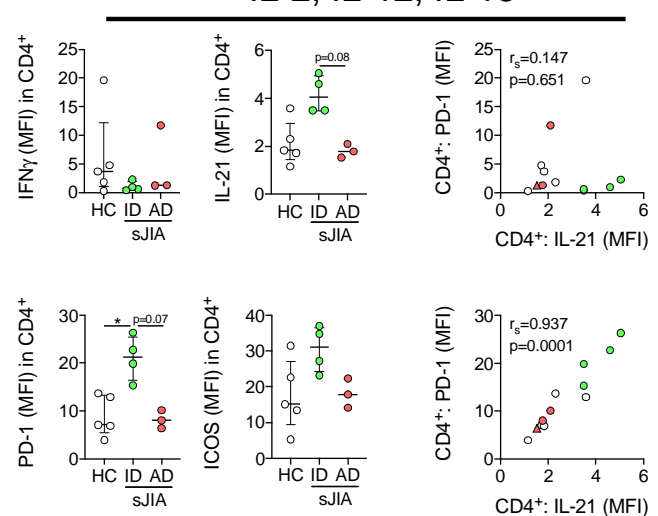

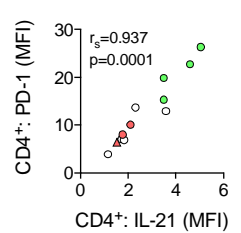

Figure S5. Early CD4+ T helper (Th) cell differentiation in systemic juvenile idiopathic arthritis (sJIA) is shifted toward a (PD-1+ICOS+CXCR5-) peripheral T helper (Tph) cell phenotype. Naïve Th cells were isolated from pediatric healthy controls $(\mathrm{HC}, \mathrm{n}=5)$, active disease $(A D, n=3)$, and inactive disease (ID, n=4) sJIA patients (see table 1) were cultured under T0, Th1, and $\mathrm{T}$ follicular helper (Tfh) / peripheral $\mathrm{T}$ helper $(\mathrm{Tf} / \mathrm{ph})$ polarizing conditions. Following six days of culture and super-stimulation with phorbol 12-myristate 13acetate/ionomycin (4h), cells were analyzed by flow cytometry. IFN $\gamma$, IL-21, PD-1, and ICOS expression (MFI, left and middle columns) and correlation of IL-21 and IFN $\gamma$ or PD-1 expression (MFI, right columns) by naïve CD4+ $\mathrm{T}$ cells cultured under the indicated conditions and following super-stimulation. Each data point presents a value derived from an individual patient or HC. Lines in scatter dot plots indicate median values. Data in left and middle columns were analyzed by Kruskal-Wallis followed by Dunn's post hoc test; $*=P<$ 0.05. Correlation data were analyzed by simple linear regression (OLS) and F-test; $r_{s}(r-$ squared value) and $P$-values are indicated. 


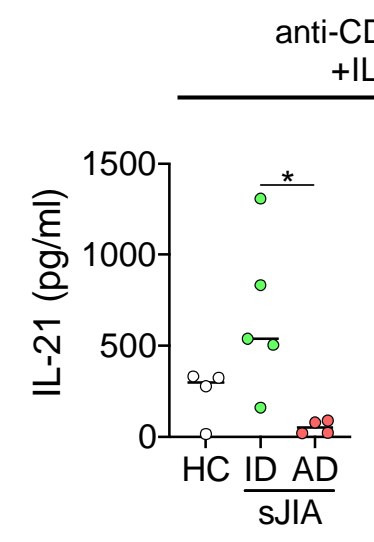

anti-CD3/anti-CD28

$+\mathrm{IL}-2+\mathrm{IL}-12$

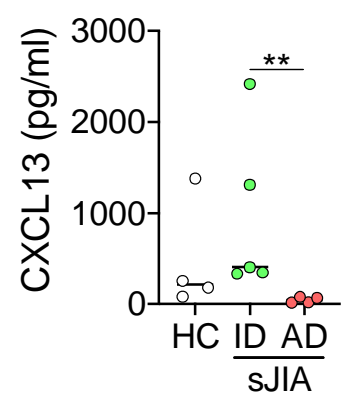

anti-CD3/anti-CD28

$+\mathrm{IL}-6+\mathrm{IL}-12+\mathrm{IL}-21$

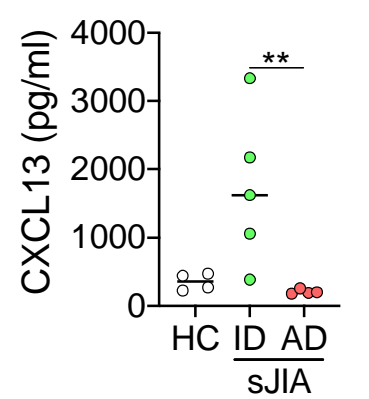

Figure S6. Developing CD4+ T helper type 1 (Th1) cells in systemic juvenile idiopathic arthritis (sJIA) release elevated levels of IL-21 and CXCL13. Supernatants of naïve Th cells isolated from pediatric healthy controls $(\mathrm{HC}, \mathrm{n}=4)$, active disease $(\mathrm{AD}, \mathrm{n}=4)$, and inactive disease (ID, n=5) sJIA patients (see table 1) cultured under indicated Th1 and T follicular helper (Tfh) / peripheral T helper (Tf/ph) polarizing conditions (6d) and super-stimulation with phorbol 12-myristate 13-acetate/ionomycin (4h) were analyzed by multiplexed bead array assay for IL-21 and CXCL13 expression. Data is shown in scatter dot plots of the measured cytokine expression in $\mathrm{pg} / \mathrm{ml}$. Each data point presents a value derived from an individual patient or HC. Lines indicate median values and data were analyzed by KruskalWallis test followed by Dunn's post hoc test; $*=P<0.05, * *=P<0.01$. 


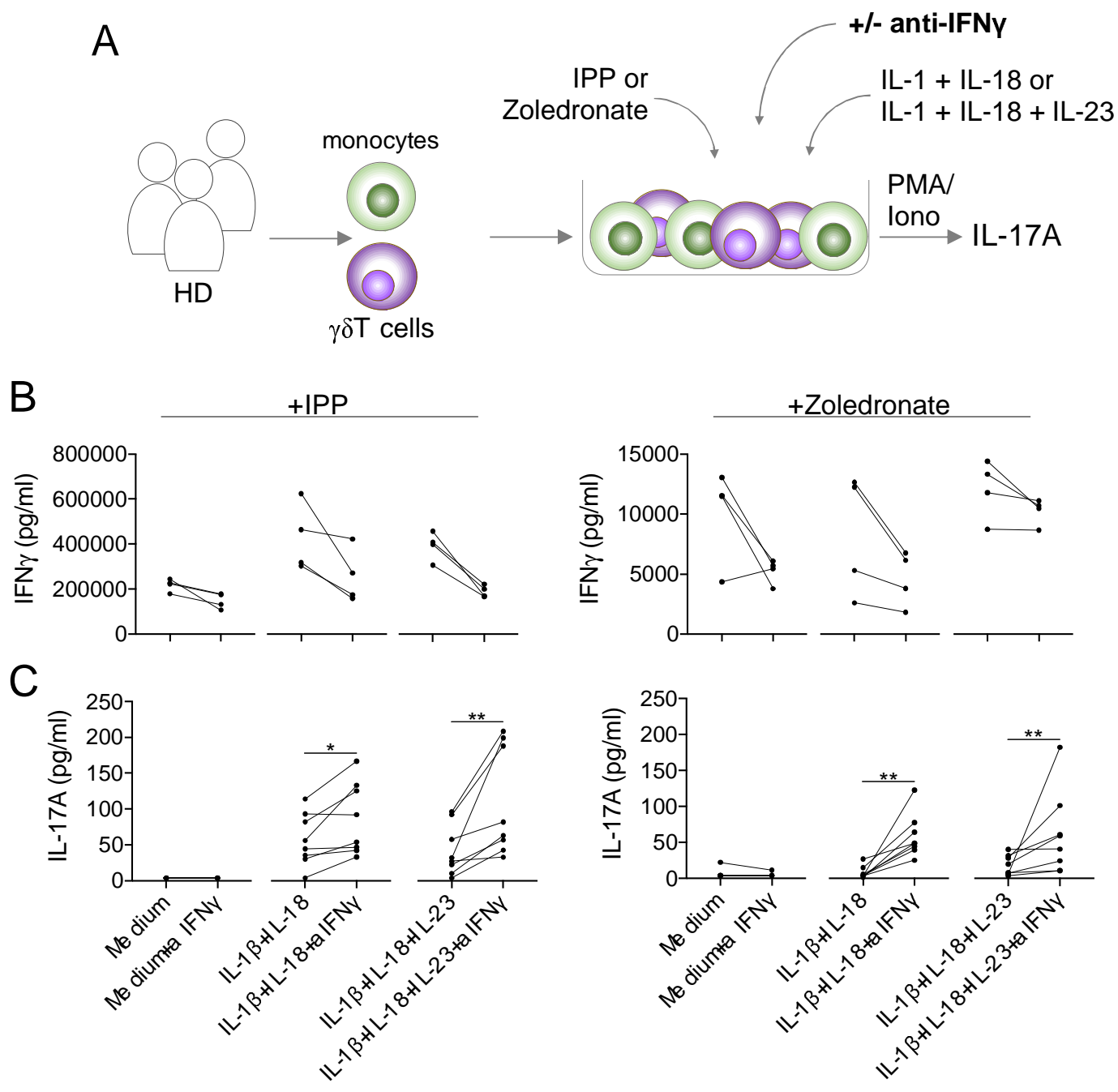

Figure S7. Low IFN $\gamma$ benefits $\gamma \delta$ T cellular IL-17A release. A-C, $\gamma \delta$ T cells and monocytes were isolated from adult healthy donors (HD) $(n=4-8)$ and co-cultured in indicated conditions supplemented with isopentenyl pyrophosphate (IPP) or zoledronate and in the absence or presence $(+$ aIFN $\gamma)$ of an IFN $\gamma$-neutralizing antibody for five days. IFN $\gamma$-depletion $(\mathbf{B})$ and paralleling IL-17A release (C) following super-stimulation with phorbol 12-myristate 13acetate/ionomycin. was assessed by ELISA. Each data point presents a value derived from an individual HD and data were analyzed by Wilcoxon signed-rank test; $*=P<0.05$, ** $=$ $P<0.01$. 